\title{
GCU
}

Glasgow Caledonian

University

University for the Common Good

\section{Developing a framework for the sustainability assessment of eco-engineering} measures

Mickovski, S.B.; Thomson, C.S.

Published in:

Ecological Engineering

DOI:

10.1016/j.ecoleng.2017.10.004

Publication date:

2017

Document Version

Author accepted manuscript

Link to publication in ResearchOnline

Citation for published version (Harvard):

Mickovski, SB \& Thomson, CS 2017, 'Developing a framework for the sustainability assessment of ecoengineering measures', Ecological Engineering, vol. 109, no. B, pp. 145-160.

https://doi.org/10.1016/j.ecoleng.2017.10.004

\section{General rights}

Copyright and moral rights for the publications made accessible in the public portal are retained by the authors and/or other copyright owners and it is a condition of accessing publications that users recognise and abide by the legal requirements associated with these rights.

Take down policy

If you believe that this document breaches copyright please view our takedown policy at https://edshare.gcu.ac.uk/id/eprint/5179 for details of how to contact us. 


\section{Developing a framework for the sustainability assessment of eco- engineering measures}

\section{S.B. Mickovski ${ }^{1,2}$ and C.S. Thomson ${ }^{1}$}

${ }^{1}$ School of Engineering and Built Environment, Glasgow Caledonian University, Cowcaddens Road, G4 0BA Glasgow, Scotland, United Kingdom

${ }^{2}$ Corresponding Author: e-mail: Slobodan.Mickovski@gcu.ac.uk; tel: ++44 141 2731105 


\begin{abstract}
The assessment of the sustainability impacts of eco-engineering strategies can be challenging and remains neglected within the literature and in practice. The challenge lies in achieving a balance between the delivery of project objectives and their alignment with the emerging principles of sustainable design which seek to provide an appropriate and satisfactory environmental and financial performance whilst delivering social benefits. Whilst it is possible to assess various aspects of the long term performance of soil bioengineering measures and the relevant projects in their delivery through cost evaluations, risk assessments and environmental impact assessments, there is currently no agreed means of assessing the sustainability performance of such measures in an integrated framework which captures the environmental, social and economic dimensions of sustainability.
\end{abstract}

To remediate this, we propose an integrated sustainability assessment framework which can be applied on any eco-engineering project. It is underpinned by a review of current sustainability indicators commonly applied in the range of sustainability assessment methods (SAMs) and best practice guidance within construction and geotechnical engineering. The framework comprises a set of key performance indicators (KPIs) reflective of the both engineering and sustainability requirements for eco-engineering in the context of stability, active use of vegetation and long-term sustainability for eco-engineering projects. Recognition is provided of the unique nature of each eco-engineering measure and provision is established within the framework for a contextual KPI subset to be developed through stakeholder engagement.

The potential of the framework was explored through an expert workshop highlighting its value to promote benchmarking across the sector between ecoengineering projects and would allow standards to emerge for establishing best practice. Through a real-life case study, we demonstrate the benefits of the adoption of such a framework at an early stage of a project but also the benefits for stakeholders which stem from double-loop learning.

Keywords: sustainability, eco-engineering, ground bio-engineering, key performance indicators (KPI), resilience. 


\section{Introduction}

\subsection{Background}

Eco-engineering or ground bio-engineering measures comprise the use of vegetation, either alone or in combination with traditional geotechnical structures, for control of soil erosion and shallow landslides (Mickovski, 2016). The characteristic that sets them aside from the traditional civil engineering or geotechnical engineering structures with a similar purpose is the fact that the vegetation is employed to perform an engineering function (e.g. soil reinforcement) but also to enhance the resilience capacity of the bioengineered structure due to the self-repairing characteristics of the vegetation used. The advantages of eco-engineering measures over traditional civil engineering solutions include value for money, ease of construction, and low landscape impact (Norris et al., 2008.). The main disadvantages in the design of these measures include the unknowns related to the living material, i.e. plants with roots and their characteristics (e.g. survival rates, spread, strength, engineering characteristics), biodiversity benefits and maintenance considerations (Stokes et al., 2014).

Eco-engineering encompasses soil bioengineering (Norris et al., 2008) and bio engineering (Stokes et al., 2010) approaches for the design of sustainable ecosystems that integrate human society with its natural environment for the benefit of both (Mitsch and Jørgensen, 2004) and, as such, should be aligned with the principles of sustainable development (Mickovski, 2016). Whilst it is possible to assess various aspects of the long term performance of soil bioengineering measures and the relevant projects in their delivery through cost evaluations, risk assessments and environmental impact assessments, there is currently no agreed means of assessing the sustainability performance of such measures in an integrated framework which captures the environmental, social and economic dimensions of sustainability. A debate exists around how an assessment method should interpret the definition of sustainability with regards to a strong definition (based around boundary limits) or a weak definition (based around accepting tradeoffs between the dimensions; Bromley, 1998 ) with the distinction recognized to greatly influence decision making. Common practice within construction and engineering tends to focus on the triple bottom line approach (Kucukvar and Tatari, 2013) which is focused on communicating sustainability performance to stakeholders to support their development of project goals and in helping shape project outcomes. In this context, the effectiveness of a sustainable assessment method (SAM) will depend on the consideration of the three dimensions (or pillars) of sustainability (economic, social, and environmental), identification of the overlapping zones and solution to the conflicts and trade-offs that exist between the dimensions therefore tending to align with the more pragmatic weak sustainability definition (Bromley, 1998). This approach seeks to present alignment with standards and best practice but not to pass a judgement on whether the project has breached resource limits as would be the case with a method such as ecological footprint which follows a strong sustainability definition (Raudsepp-Hearne et al., 2010).

Eco-engineering systems include the environment (soil, water, air, flora/fauna, society), inert and live construction materials and the interactions between these. The 
main purpose of these systems is the stabilization/reinforcement of the soil (Schiechtl and Stern, 1996) or to avoid major disruptions and collapses while hedging against instabilities and discontinuities, thus seeking to ensure physical resilience and long term sustainability of the system (Costanza and Patten, 1995). Eco-engineering measures are often said to provide a combination of sustainability benefits such as protection against soil erosion in the short-term and the long-term stabilisation due to the reinforcement effect of the roots on the soil (Gray and Sotir 1996, Norris et al. 2008). While the biological and ecological aspects of ecological engineering have been extensively studied, the technical aspects and the socio-economic issues associated with soil bioengineering are not usually quantified in practice (Stokes et al., 2014). Furthermore, eco-engineering measures comprise systems and subsystems with a necessarily finite life span (longevity) which are hierarchically interconnected over a range of time and space scales which is another characteristic of sustainability.

Because of the above, eco-engineering measures are considered by many to be a more sustainable alternative to traditional hard engineered solutions due to their greater alignment with natural systems (e.g. Stokes et al. 2014). Traditionally, ecoengineering works would take place either very early in the project to allow for vegetation establishment or very late to allow for monitoring of the performance. Ecoengineering practices can significantly help in reducing costs and risks (Norris et al., 2008) while, at the same time, achieving the sustainability credentials of the project both from a biomimicry perspective but increasingly from its contribution to society through its aesthetics, potential for resilience and whole life value. However, not unlike the concept of "fitness" in evolutionary biology, the determination and quantification of sustainability can only be made after the measure has been put in place and only with an appropriate structured set of performance criteria applicable to eco-engineering practices (Swan and Kyng, 2004). The sustainability benefits of ecoengineering measures have not been quantified in the past, perhaps due to, a lack of awareness of the sustainability agenda or its value; lack of an agreed means of interpreting it in the context, lack of mechanisms and frameworks for quantification of these benefits and lack of emphasis on long-term monitoring (Mickovski, 2016). These challenges have contributed to the dominance of the objective-based assessments such as BREEAM (http://www.breeam.com/), LEED (https://new.usgbc.org/leed) and CEEQUAL (http://www.ceequal.com/) which are sustainability assessment methods (SAMs) developed for the wider built environment and focus on benchmarking sustainability performance of construction projects. They reflect a mix of quantifiable and subjective indicators with the aim of providing stakeholders a holistic view of a construction project's sustainability performance (Swan and Kyng, 2004) whilst acknowledging the difficulties of providing accurate measures which engineers would otherwise rely on.

Key Performance Indicators (KPIs) are part of the benchmarking process commonly used in the construction industry (Swan and Kyng, 2004) and are an important basis for establishing an objective based SAM. A benchmark is a level of performance that allows comparison between projects in order to achieve 'best practice' through continuous improvement of the performance. KPI is the measure of a process that is critical to the success of the project and a common set of KPIs within an industry based on best practice and regulations allow benchmarking of an organization or a project against the standards achieved within industry. While KPI benchmarking systems relating to sustainability have been introduced to the construction industry as 
a whole in the last decade (Swan and King, 2004), there is a lack of KPIs and benchmarking systems for the eco-engineering industry which would enable knowledge acquisition and transfer and promote the best practice within the practitioners' and managers' community (e.g. Studer and Zeh, 2014). Such a system would also demonstrate compliance with internal/external reporting regulations (e.g. ISO 2004, ISO 9000 and ISO 14000 series) and facilitate transparency for information sharing. This would increase the visibility of eco-engineering as a specialist and multidisciplinary branch of the construction industry. For this, a comprehensive set of KPIs will be essential to underpin an objective based assessment seeking to enable the measurement of accomplishments, demonstrate transparency to stakeholders and build a knowledge base for the professionals involved.

\subsection{Research aim}

The aim of this research is to critically review the most widely used SAMs applied across the broader construction industry and their KPI frameworks to adopt a suitable integrated framework that will satisfy the requirements for assessing a project's sustainability performance in relation to eco-engineering aspects. The framework will seek to capture quantifiable measures as well as the more subjective dimensions of sustainability in an acceptable manner. A set of common benchmarks (KPIs) will be developed reflective of the principles of sustainability which can then be contextualised for the individual context of an eco-engineering project through stakeholder consultation/engagement. The application of such a framework and the associated KPI will then be illustrated with a case study from Scotland at Bervie Braes, Stonehaven and its potential explored through an expert workshop. The framework and lessons learnt will provide the basis for the future development of a SAMs for eco-engineering.

\section{Materials and Methods}

\subsection{Research strategy}

To identify an appropriate sustainability benchmarking framework and set of KPIs specific to eco-engineering, the research followed a pragmatic approach with published information drawn on to establish an initial framework based on existing research and best practice, policy and regulations. This was contextualised through a set of interviews with industry and engagement on four construction projects comprising eco-engineering component (case studies) where more than 40 site visits were carried out within a four-year period to inform the development of the framework (Figure 1). Twelve semi-structured interviews with a range of stakeholders such as clients, designers, contractors, Local Authority (LA), engineers, and members of the communities adjacent to the study sites were conducted within this period with key themes emerging from the response of the parties involved. The interviews were recorded, then analysed using thematic analysis and triangulated in conjunction with project documentation and records (Braun and Clarke, 2006) in order to inform the development of the KPIs framework and establish lessons for the future development of an applicable SAMs. The case studies sought to outline the types of problem associated with the application of eco-engineering measures and to establish an understanding of current practice in Scotland. Applying the developed KPI 
framework to a case study and critically analyzing it from sustainability point of view allowed identification of potential obstacles for future application and lessons for developing future SAM.

This two-stage approach allowed a conceptual model to be established based on existing knowledge whilst the case studies enabled an empirical inquiry permitting analysis of eco-engineering concepts and the sustainability background in their "reallife context" (Yin, 1994). As the research was problem-based, this descriptive and explanatory approach provided a pragmatic analytic framework around which to explore the complexity and challenge of delivering eco-engineering measures while analysing the design, decisions, policies, institutions, and stakeholder engagement during the life-time of the project.

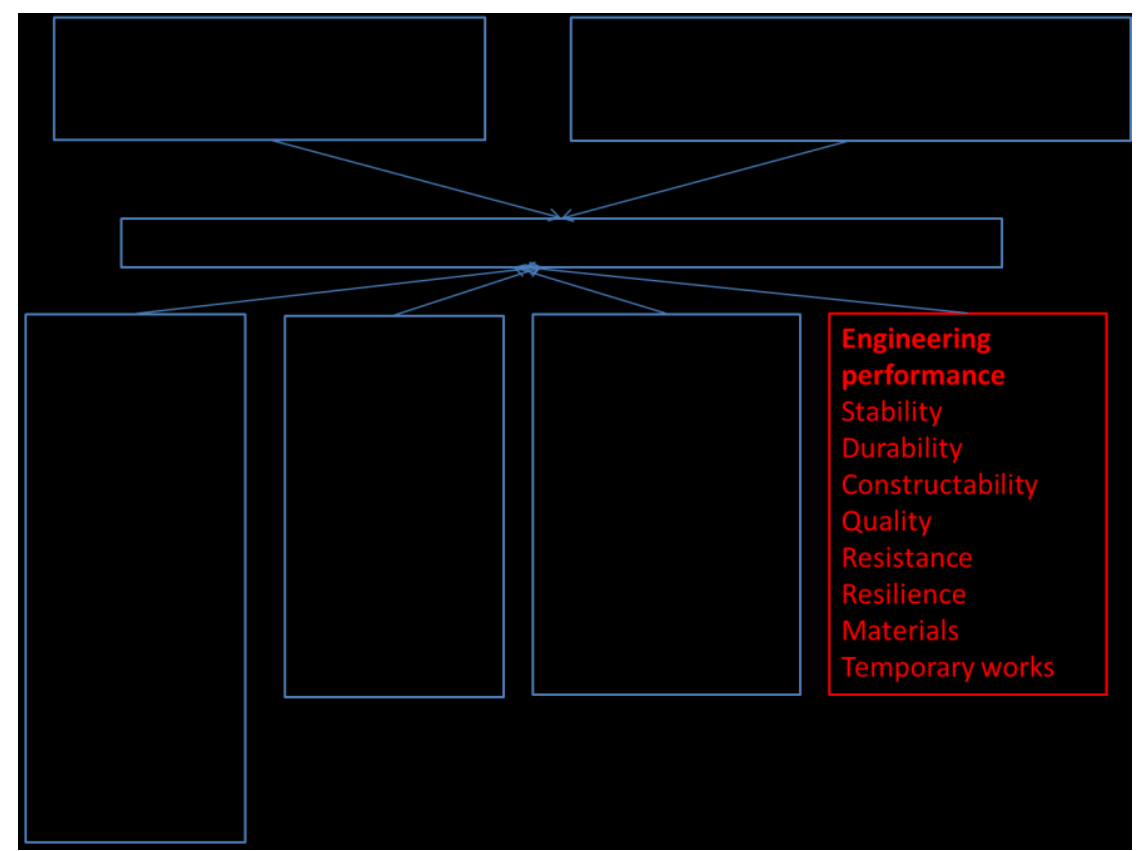

Figure 1 Conceptual framework for development of sustainability KPI for eco-engineering. (adapted from Lim, 2009). The Engineering Performance KPI set is a novel addition to the traditional sustainability KPI sets.

\subsection{Review of existing systems}

In developing a framework applicable for eco-engineering it is important to review and understand the dominant approaches in the design of sustainability assessment methods and the lessons learned from their application within the built environment. BREEAM (Building Research Establishment's Environmental Assessment MethodUK) and LEED (Leadership in Energy and Environmental Design- USA) are the two dominant building sustainability assessment methods (BSAMs) and are widely applied internationally to assess building sustainability performance but many developed nations have their own domestic methods which reflect the national context, priorities and offer certification (Cole, 2005). CEEQUAL is a SAM applied for civil engineering projects and is also developed by the Building Research Establishment for reflecting broader sustainability agenda for the context of generic infrastructure projects with reflective criteria and indicators. Among these, the Land 
Use, Landscape, Ecology and Biodiversity, Energy and Carbon can be closely related to eco-engineering.

Primarily objective-based and assessing compliance with nationally recognised best practice and regulations, the above systems are used by stakeholders to showcase their sustainability credentials and expertise within their desired markets (Walton et al. 2005). The preference for this approach has been driven by the national governments seeking alignment with government policy in order to promote sustainable practice through public procurement and planning regulations. These SAMs integrate the three sustainability pillars in projects beyond current practice, regulations and wider environmental obligations but remain largely tied to environmental criteria and fail to provide the holistic interpretation that includes the social and economic dimensions (e.g. Gibson, 2012). Despite the differences, the overall framework underpinning these methods allows the performance to be compared through the communication of the outcomes through understandable labels (e.g. for BREEAM- Good, Very Good, Excellent and Outstanding) which have become recognised benchmarks for sustainability performance amongst stakeholders (Thomson and El-Haram, 2014). While the BSAMs have helped to promote a common approach to delivering sustainable design and construction, this has left projects seeking a more developed set of KPIs with a requirement to apply additional assessment methods in order to address the gaps but this is complex and only pursued by those committed to sustainable construction.

Recent years have seen a conceptual evolution in SAMs with the practitioner in mind (Bond et al. 2012), where new SAMs play a more progressive role in informing and shaping project decisions but also act to allow stakeholders to reflect on the impacts and knowledge considered, generated and exchanged during the assessment process (Cole and Valdebenito, 2013; Morrison-Saunders and Pope, 2013). Given the growing significance of the impact of climate change and other environmental degradation (Mickovski, 2014), understanding the impact of the intervention is important but, significantly, the eco-engineering SAM should have the potential to help stakeholders consider the role which the intervention places to the context of society and whether it represents good economic value in the long term. Furthermore, such system should take into account the main aim of the design of sustainable eco-engineering measures: to provide an economically competitive construction with higher utility value, lower energy demands, lower raw material input, and lower need of new land for development while minimising the risks on human health and life during the lifetime of the measure, including natural disasters and accidents (Vaniček et al. 2016; ECTP reFINE, 2012). Additionally, with growing calls for SAMs to be increasingly aligned with the development of a project (Bond et al., 2012) it is important that this is reflected in developing a SAM for eco-engineering which helps stakeholders shape projects goals and objectives, guide design, monitoring during construction and then enables assessment of its contribution over its post construction lifetime.

In this sense, the Environmental Geotechnics Index (EGI) (Jefferson et al., 2007) approach can be used to measure sustainability of the project from inception to long term use, ensuring coverage of the three pillars of sustainability in each project stage. A benefit of adopting the EGI approach is that it allows the decision maker to recognize the issue and assess the viability of potential alternative solutions based on the sustainability drivers. EGI is a proactive SAM underpinned by 108 indicators 
which performance can be measured using a 1 to 5 scale and the output presented using a radar diagram to facilitate communication to project stakeholders for each of the 8 project phases, similar to other SAMs (El-Haram et al., 2007, 2009).

None of the existing SAMs, however take into account the engineering performance of the project and this will have to be considered with a newly developed set of KPIs for which a range of stakeholders were consulted and contributed to.

\subsection{Stakeholder contribution towards the development of eco-engineering KPIs}

Current client requirements on tenders including eco-engineering measures are based on assessment of project value (price) and quality assurance (QA) which, in turn, broadly encompasses the sustainability benefits and credentials of the tenderer. The interviews with the client organisations revealed a general view that it would be easier for the client and decision makers/funders to have easily comparable quality submissions and one of the drivers for developing a common system would be enhancement of the procurement process (Mickovski et al. 2013) and aid alignment/ integration with the project management with a view to shaping decision making across project phases (Thomson and El-Haram 2014).

Analysis across the interviews identified structural stability and the cost of the overall project as the main drivers emerging for application of eco-engineering measures. This aligns with the dominant perception of sustainability benefits being offered by eco-engineering measures being associated through the immediate aim to stabilize the slope using shortened time for natural succession at low maintenance costs and creation of economically usable areas (Schiechtl and Stern, 1996). Most of the interviewees expressed concerns about eco-engineering design for stability, mainly connected to the absence of governing standards, lack of long-term recording and monitoring of the behavior of such measures, as well as the lack of comparable evidence in terms of case studies which was in line with what was reported in the literature as a disadvantage of the eco-engineering measures (e.g. Stokes et al. 2014). In this respect, the interviewees considered the use of eco-engineering measures as a possibility, mainly in combination with traditional stabilization measures.

From a construction point of view, most of the interviewees voiced concerns over health and safety of the workforce (working on slopes, working at or near water, working with potentially invasive plant species, etc.). The participants agreed that the eco-engineering measure construction should protect erodible slopes with an effective plant cover and unstable slope by ground stabilization both in short and long term. It was considered that the original design may be subject to change during construction because the site conditions and availability of the materials are likely to influence the choice of plants and type of measure implemented. In this respect, the interviewees stated that appropriate ground investigations should be carried out before the design and the contractors should be involved in the design from an early stage in order to familiarize themselves with the site constraints and best use their experience. Similarly, accent should be put on planning of the eco-engineering measure construction due to the planting and other environmental constraints which is in line with the expectations noted in the literature (Schiechtl and Stern 1996; Coppin and Richards 1999). 
There was a noticeable discrepancy in the views expressed by interviewees coming from client and contractor organisations: clients tended to require "low to no maintenance" of the applied measure in the long term; while contractors offered warranty limited to a specified defects correction period. All respondents considered the long term monitoring of the applied measure as beneficial but tried to avoid liability. The general view was that long term monitoring may increase the confidence in the robustness of eco-engineering measures but recognised that risk management planning is necessary and should include some measurement of resilience of the measure as well as consideration of the long term during development of any contract but also in the design of the measure to ensure whole life value is sought.

\subsection{Development of the eco-engineering sustainability KPIs}

When adopting the general framework, the generic benchmarking methodology was followed (Swan and Kyng, 2004) with project performance compared against sustainability themes identified through the comparison of existing SAMs and input from industry. Seeking to reflect a holistic coverage, a set of eco-engineering KPIs were developed in order to benchmark the current performance and generate an enhancement plan to drive the performance towards the benchmark level. The benchmarks were reflective of national priorities and informed by best practice and guidance (e.g. Swan and Kyng, 2004; Norris et al. 2008; Stokes et al., 2014). To achieve this, it was considered appropriate to break down the process in project stages having the sustainability considerations as a common background and driver for development of the KPIs (Figure 2) thus ensuring the framework is embedded and helps shape project decisions, thus responding to calls for SAM's integration with reflective project management observed in Thomson et al. (2011) and Thomson and El-Haram (2014).

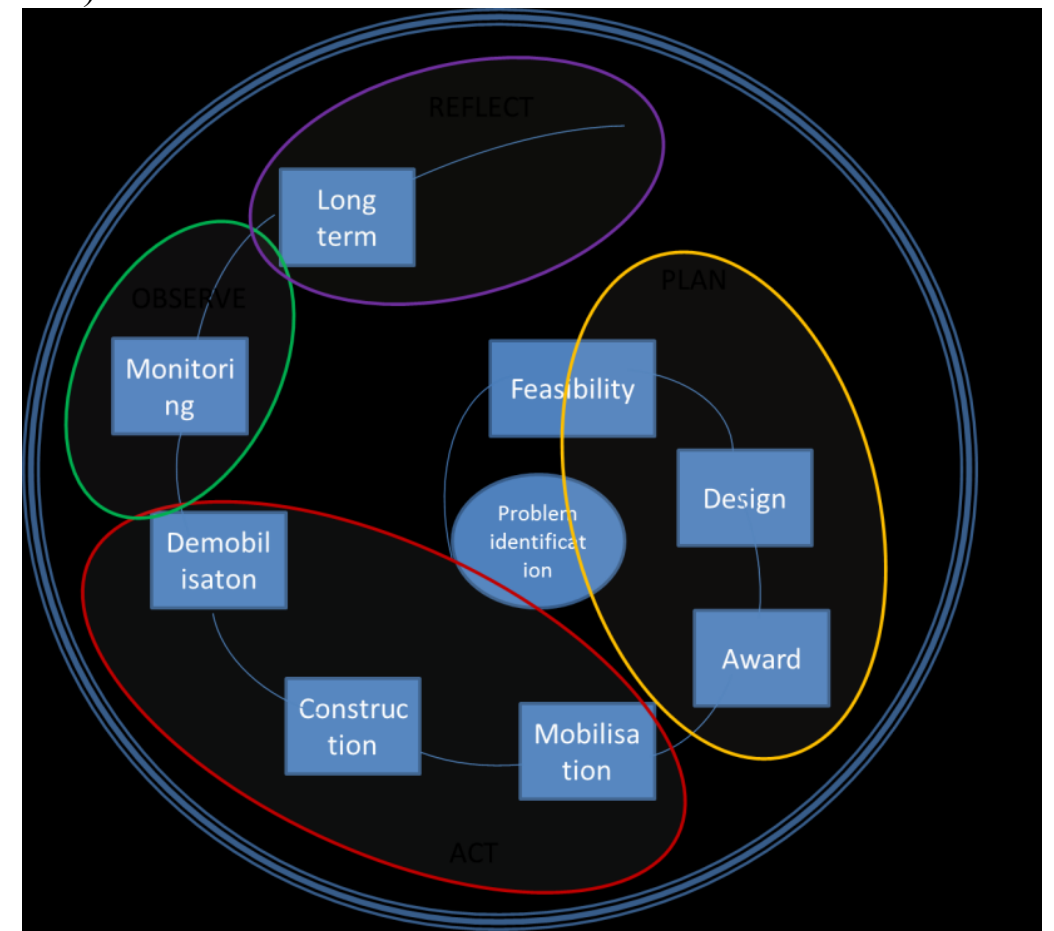

Figure 2. Eco-engineering project phases where sustainability needs to be taken into account 
Aiming at ensuring the indicator criteria are seen as applicable and designed in a way that enables creative engineering without manipulating the application of the SAM, the basic sustainability aspects (Figure 1; El Haram 2007, 2009) were enhanced with the engineering performance of the eco-engineering measure which has been identified through the interviews and is considered as a novel addition to the existing frameworks. The economic KPI were developed to broadly cover the costs and expenditure throughout the project as well as to identify any potential savings in terms of time and resources (Mickovski et al. 2013). The social KPI covered the public participation, community engagement and social benefits such as recreation, public health and employability (El-Haram et al. 2009) re-contextualised to be more reflective of the natural environment. The environmental KPI comprised the effects of the design, construction and maintenance/decommissioning on the environment in terms of water, air, soil, flora and fauna (Schiechtl and Stern 1996; Grey and Sotir, 1996; Norris et al., 2008; Stokes et al., 2014). The performance KPI covered the engineering aspects of the project in terms of stability, durability and resilience (Coppin and Richards, 1999; Mickovski, 2014).

\subsection{Case study}

The Bervie Braes comprise an approximately $750 \mathrm{~m}$ long slope above the harbour in Stonehaven which provides the backdrop to the town and is designated as a conservation area. The slope has been monitored by the council for decades because of an ongoing history of movement which has manifested as road settlement, surface circular slips and recent shallow failures at a number of locations and led to the closure of the former trunk road traversing the slope. The issue of repair works and safety has been documented in the printed and electronic media both locally and nationally (Currie et al. 2009), before the stabilization works were procured and the measures constructed in the following project stages:

Feasibility: The Local Authority (LA) issued and awarded a tender to undertake a forensic investigation including a detailed ground investigation to determine the ground model and possible failure mechanisms at the site based on the history of the site. The ground investigation comprised intrusive and non-intrusive ground investigation including boreholes, trial pits, inclinometers, piezometers and geophysical seismic modelling which helped in outlining the possible causes of instability and informed the potential stabilisation design solution.

Design: As part of the feasibility study, a total of 9 specimen design options for stabilisation of the Braes including soil nailing, retaining wall, reinforced earth, and rockfill solutions together with the drainage and revegetation design were identified. Recognising that the proposed works are of public interest and for the welfare of the local comunity, the LA consulted with the the wider community who voted for mixed stabilisation method (soil nailing, planting/seeding, earthworks, and drainage works) in light of the minimal disruption and green slope finish they can provide. The specimen design also included an Emergency Plan for the LA to use in case of heavy rainfall and rising groundwater which was based on an installation of a remote groundwater monitoring system with real-time alerts. The LA appointed a Designer to carry out the detailed design for the landslip prevention measures which was completed on time and budget and presented to the local community at a Public 
Consultation event where the community was engaged in clarification of technical, sustainability, and legal aspects of the works.

Procurement: Following the completion of the detailed design a NEC3 type contract was prepared for the construction stage. Due to the limited funds available for the project (Mickovski, 2014), the Designer adopted a risk-based approach in prioritising the stabilisation works in the areas that were showing signs of instability or could potentially become unstable. This resulted in a tender that had fixed elements (areas and works that had to be stabilised/carried out in any case such as the ecoengineering, drainage, and critical stabilisation works) and variable elements (stabilisation works in areas of lower priority), offering a chance for the successful tenderer to stabilise as large a proportion of the slope as possible and provide value for the funds secured by the LA. Sustainable alternatives and potential savings were discussed and agreed between the Designer, Client (LA) and Contractor before signing the contract.

Mobilisation: A number of formal and site meetings were held before and during the mobilization stage to discuss and agree the approach towards construction in terms of health, safety, environmental and sustainability. The Contractor was introduced to the residents and the Community Council who transferred local experience to the contractor in terms of deliveries to site and organizing the utility service disruptions. Due to skill resourcing issues and in accordance with their programme, the Contractor decided to mobilize workforce from their HQ location, some $400 \mathrm{~km}$ away from the site, and to work longer hours during a 4.5 day long working week. The challenges at this state included phasing of the works to avoid the bird-nesting season as well as specification for selective removal of low-value trees and shrubs from the slope prior to commencement of the main works to facilitate the soil nailing operations. In preparation for construction, a number of shrubs and young trees were excavated and stored for replanting to enable the construction plant movement and operation.

Construction: The construction phase works comprised structural stabilisation using soil nails, slope protection against erosion and shallow landslides in terms of planting and seeding, but also additional drainage measures and full landscaping at a number of slope sections. The soil nails utilised an innovative head assembly, recessed within the slope and covered with pre-seeded biodegradable bags providing a green slope finish and resistance to erosion in the short- and long-term. More than 120 native trees were planted after the completion of the nailing to provide both stability and a natural green finish of the slope. Promoting sustainability and providing an added value to the client, the design included a new robust road drainage system discharging into the adjacent watercourse and an upgrade of the existing surface water system at the toe of the slope that collects the water drained from the stabilised slope and discharge it into the old harbour, thus minimising the risk of flooding and slope instability at the toe of the slope.

De-mobilisation and monitoring from the site were phased because the contract type supported phased delivery but also because of the pressure from local community to have parts of the site available for recreation and tourism available as soon after completion. The eco-engineering works, in conjunction with the landscaping works, were phased towards the end of the construction works. These works required only periodic monitoring within the defects correction period which did not require site 
closure or any disruption to any services. In consultation with the local community, the properties affected by the works were returned to at least the condition before the works while the stored shrubs and young trees were re-planted during the dormant period. Monitoring of groundwater conditions and slope movements using solar and wind powered sensors continued beyond the defects correction period, while occasional inspections were used to confirm the success rate of the vegetation and any need for maintenance.

In the long-term (beyond the defects correction period) the benefits of the site were enhanced by partial opening of the road traversing it and inclusion of a cycle track adjacent to the road, both of which improved the access to the old historic town, the connection of the town and the nearby tourist attractions, and the enhancement of the recreational facilities locally. The local community was engaged in any minor repairs to the planted/seeded areas and kept informed on any develoments by the LA.

2.6 Expert workshop

To aid the development of the framework and ensure that it retains international relevance to experts from both academia and industry (designers and contractors from big and small companies), a workshop was convened as part of the International Symposium on Soil- and Water-bioengineering in a Changing Climate (Glasgow, $7^{\text {th }}$ $8^{\text {th }}$ September, 2017), where more than 50 delegates from a number of European countries (UK, France, Italy, Spain, Portugal, Greece, Germany, Austria, Turkey, and FYR Macedonia) represented researchers of international standing in eco-engineering and a strong mix of practitioners representing all aspects of the development process.

\section{Results}

\subsection{Development and adoption of a benchmarking framework}

Based on the review of the current SAMs applied within the built environment, their approach and KPIs and the drivers identified in consultation with the industry, an objective-based approach drawing on the EGI system was selected as the most appropriate basis for development of eco-engineering KPIs. The original EGI system was reviewed in line with its philosophy and the identified drivers: some of the generic KPIs which were not applicable were replaced with equivalent KPI relevant to eco-engineering and the wider review (i.e. SUE-MoT indicators; El-Haram et al. 2007). Additionally, eco-engineering-specific KPIs were developed as a novel approach. This resulted (Tables 1-8) in a system of 117 KPIs (including 44 new, ecoengineering-specific KPIs) that can be used to assess the sustainability performance of eco-engineering projects on the lines of the criteria detailed in section 2.4.

\subsection{KPI for eco-engineering}

The new, eco-engineering-specific KPI were developed based on the existing guideline documents (Grey and Sotir 1996, Schiechtl and Stern 1996; Coppin and Richards 1990; Norris et al. 2008; Studer and Zeh, 2014), decision support systems (Mickovski and van Beek, 2006), and technical literature (for review see Stokes et al. 2014). The quantification of the effect on sustainability was guided by the requirements shown in section 2.4 and the practical guidelines in the above literature 
with positive effects and scoring above the sustainability status quo given to strategies such as the use of native, non-invasive plant material; recycling/reuse of construction waste (or material available on site); minimising energy input (e.g. transportation, plant use, manual labour, energy for investigation and monitoring); increase in social acceptance (public consultation, community engagement, recreational value, recreation, employment); delivering to project timeline and budget; providing both long- and short-term stability; enhancing health and safety at the site. Following the approach used in other SAMs (Jefferson et al., 2007; El Haram et al., 2009) the outputs of individual indicators were developed in relation to a constant 1 to 5 rating which would provide the assessors the alignment of individual indicators with benchmarks to rate where the current project sits in relation to a comparable level of performance. The total score for each stage of the project was derived as an average score of all KPIs in that specific stage. With this, a common scale was applied, and through the use of a radar diagram the level of performance was considered visually throughout the project lifetime. The level of sustainability performance of the ecoengineering measure was, thus, simple to communicate to stakeholders at different phases of the project, identifying the strengths and weaknesses.

\subsection{Application in the case study}

The application of the adopted framework with the newly developed eco-engineering sustainability KPI in the representative case study resulted in sustainability assessment of each project stage (Tables 1-8). Figure 3 shows the summary of the sustainability performance of the case study project broken down to project stages and in reference to 'neutral' sustainability performance that indicated level of actions that neither enhance nor reduce the sustainability. This summary shows that during the case study project, the actions prior to the mobilization on site were contributing towards the improvement of the sustainability, while the majority of the other project stages showed performance just below the neutral effect on sustainability. The only project stage that showed reduced sustainability was the mobilization stage. 


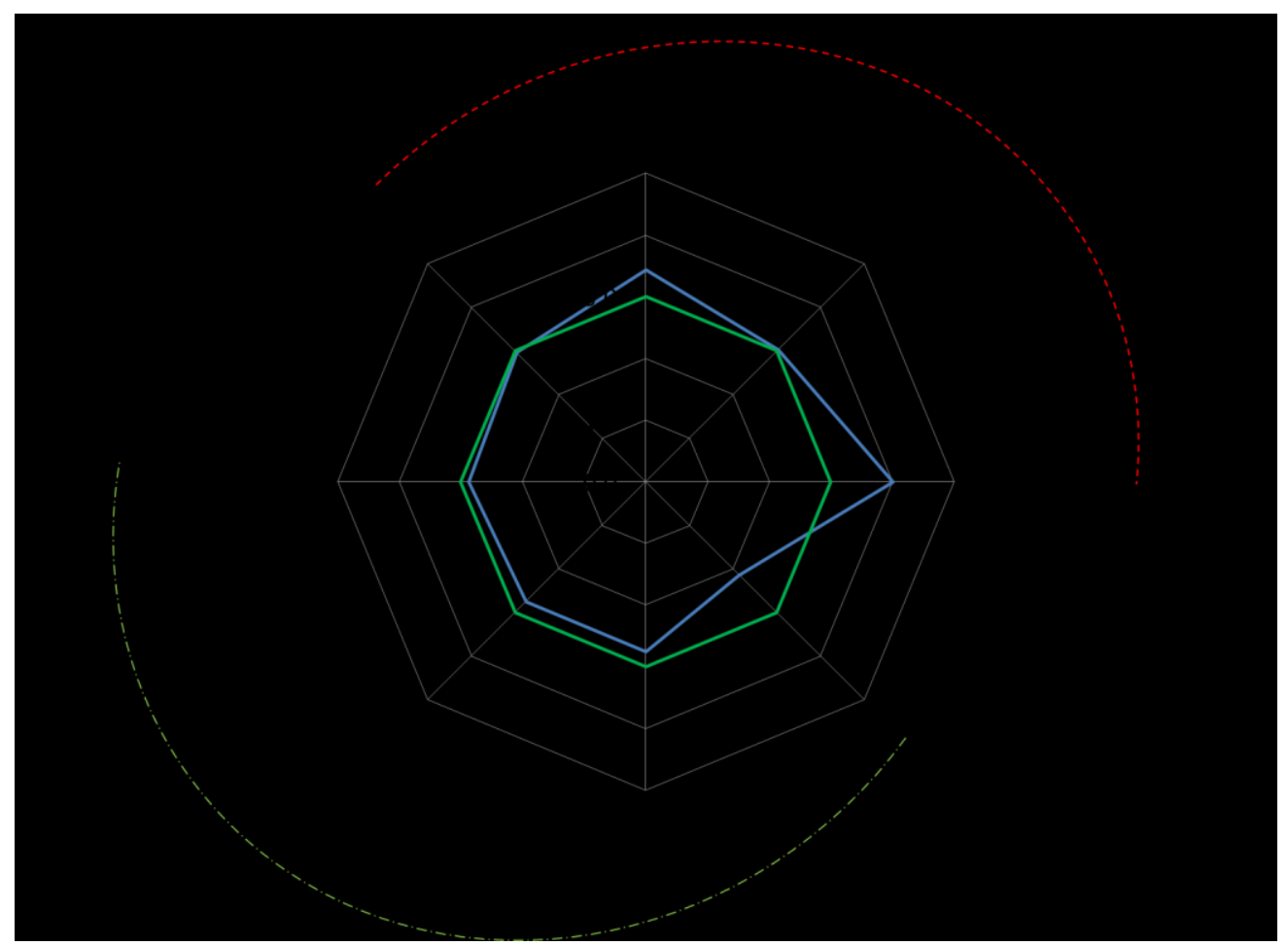

Figure 3 Sustainability performance of the project through different project phases (blue line) compared to the 'neutral' sustainability performance (green line). Sustainability ranking: 1- Harmful; 2- Reduction; 3 - Neutral; 4- Improved; 5- Significantly improved.

\subsection{Expert workshop}

The participants were broadly in favor of the development of such a framework and stressed that its key role would be as a communication tool to aid decision makers in ensuring that sustainability was valued during the development process. Emphasizing the value across the lifecycle, the participants stated that such framework will ensure that trade-offs between the sustainability dimensions have been considered and enable non-economic criteria to be valued during this process. A key discussion emerged around the operationalization of the framework in practice and the number of KPIs which project teams would be able to resource in terms of data collection and evaluation. These concerns relate to wider debates around the evolution of SAMs in other sectors regarding whether a large detailed set of indicators was more effective or whether a simpler less detailed set can convey just as satisfactory an outcome to help decision makers (e.g. Thomson et al., 2011). Eco-engineering interventions within a construction project can often be small in scale and with limited budgets, and a challenge exists for project managers to adequately resource such an assessment. In addition, a more complex framework would require a trained professional to conduct the assessment which could be difficult to resource. The delegates aired the view that many of the indicators are aligned to legislative requirements in their respective countries and much of the data and evidence required is already being generated as part of the design process so the number of proposed KPIs may not be such a concern. However, with such a strong alignment with legislative requirements the framework would need to be contextualized for regional and national contexts. 


\section{Discussion}

The aim of our study was achieved by developing a framework for sustainability assessment which includes a specific eco-engineering KPI set, and adoption of an appropriate representation of the outcomes in a diagramatic form. The key objectives were achieved by placing the stakeholders at the centre of the development process where the role of the KPI was to inform their decisions about where to focus in their future efforts in order to achieve the sustainability goals. The eco-engineering framework developed here will help the stakeholders to shape projects goals and objectives, guide the design, monitor during construction and assess the project contribution towards sustainability over the post-construction lifetime. Additionally, the developed framework can be used for comparison between projects (by aligning with an objective-based approach promoting benchmarking) while resisting the temptation to seek an overall sustainability value for the project (Swan and Kyng, 2004). Finally, the objectives were also achieved by developing a framework without a weighted output which would prioritise specific sustainability themes reflected in current BSAMs such as BREEAM.

The proposed framework is in line with the current SAMs in terms of promoting a common approach to delivering sustainable design and construction (e.g. Boer at al 2013; Singh et al., 2012). The novelty is the inclusion of a set of KPIs, which are both eco-engineering-specific and cover the social and financial aspects of the project. The developed KPIs were SMART (Ahmed and Sundaram, 2012): discipline Specific indicators that convey at a glance what it is each KPI is measuring; that are Measurable either as an objective value or a data that is already being measured or can be easily collected; that are Achievable in terms of an output within the program or activity's manageable control; that are Relevant in terms of measuring the most important result of the activity; that are Time-bound in terms of achieving them and reporting them in a specific project phase to support tracking and management of decision making. This approach employed to develop the KPI makes them compatible with the other Quality Assessment or Quality Management systems (e.g. Health, Safety, Environment and Quality; Zeng et al. 2010) in terms of access to data input for the KPI framework which is measured as part of the other processes (Srdic and Selih, 2011). This will decrease the need for application of additional assessment methods in order to address the sustainability gaps.

The bias towards environmental performance which has been criticized in the existing BSAMs (Gibson, 2012) has been alleviated with the inclusion of KPIs directly aimed at measuring social sustainability ( $10 \%$ of the KPIs; e.g. Community engagement plan, Stage A), economic sustainability ( $8 \%$; e.g. project cost over-run, Stage F), and engineering stability (10\%; e.g. Vegetation function in the design, Stage E). Approximately $20 \%$ of the rest of the KPIs are indirectly related to the socioeconomic sustainability (e.g. Land intended for use by business and/or infrastructure, Stage B).

Trying to avoid the common pitfalls when developing the eco-engineering specific KPIs (e.g. Swan and Kyng, 2014), effort was made to benchmark the most generic eco-engineering actions and applications such as seeding and planting that feature in 
some form in all eco-engineering strategies. The developed 44 specific KPIs (38\% of the total number) are considered to be appropriate in quantity and coverage, can be used on their own for measurement of eco-engineering performance only, and can be used as a basis for development of KPI for other techniques in the course of time. The case study demonstrated the application of the framework which can be used to ensure the process of application is understood (Jefferson et al., 2007; Swan and Kyng, 2014) before applying it to new projects.

The case study application showed discrepancy between the office-based project stages (A-C) and site based activities (D-H), i.e. between planning and construction. In terms of sustainability performance, this can be explained from both driver and management aspects. While the planning activities were mainly driven by client and public requirements which the detailed design incorporated, the site activities were driven by program management in terms of resourcing and budget by the contractor. Earlier involvement of the contractor in the planning process would have contributed towards better understanding of the design and construction requirements for sustainability by familiarizing with the best available practice and budget planning to meet the project targets. Similarly, had a similar benchmarking system been available early in the project it could have been used as a planning tool in conjunction with the construction programme and resourcing of local labour during the mobilization stage could have been enhanced. The case study assessment also shows that sustainability should have been signposted as a driver throughout the project lifetime: from assessing contractors suitability (i.e. through Pre-qualification questionnaires - PQQs) through design of robust and resilient measures to construction and maintenance that will minimize the effects on the environment while in the same time providing value for the project stakeholders. Implementing this in the site-based activities would have contributed towards ensuring that the project develops retaining a focus on the whole life value (ensuring that sustainability can be grounded in issues such as maintenance and restoration over time).

The objective-based approach of BSAMs can give rise to a culture of mere compliance with the regulations and will limit the space for projects and professionals to reflect and learn from their own practice (Thomson et al., 2011). Inspiring a culture to promote innovation and creativity within the design and construction of a project is necessary if the eco-engineering projects are to deliver the level of change sought. That is why the presentation of the outputs in an integrated manner was a key to the valuable role this framework could play in communicating project sustainability performance to stakeholders in a holistic manner as identified in section 2 . The challenge here was to find an effective matrix around which to aggregate the performance level for each of the indicators without giving more weight to certain themes, trying to reduce the outcomes to a common currency (Singh et al., 2012), permitting trade-offs which can result in problem areas remaining unresolved and providing those seeking a quantifiable measure certainty in an inexact science (Swan and Kyng, 2014).

The current framework was developed based on input from projects in Scotland and the UK sustainability legislation. Future research should focus on validating this framework across a range of eco-engineering strategies and bio-geo-climatic regions using case studies as suggested elsewhere (Stokes et al., 2014). The lessons learned from this together with the basis set out in this paper would help the development of 
an operational sustainability assessment method contextualized for eco-engineering. Such model could include more specific KPIs for different eco-engineering measures (Jefferson et al., 2007), consolidated generic KPI sets and could be used as a planning tool throughout the project lifetime (El Haram et al., 2009). In this respect, the current KPI relevant to UK may be replaced with the corresponding legislation elsewhere or the framework can be used to develop and adopt new legislation that promotes sustainability through eco-engineering.

As a tool, this model would increase the visibility of eco-engineering profession and give a competitive advantage to the eco-engineering professionals who would be assessing the sustainability performance (Rey et al., this issue). In this respect, it is recommended that the assessor is an integral part of the team participating in the decision making process in order to permit transfer of knowledge with and from the team, rather than being external to the team with a task of providing a report based on received data and not being able to influence performance improvement (Thomson and El-Haram, 2014). The training of staff in the use of the framework can be introduced as a part of the quality assurance system of the company and promoted by the professional organisations (e.g. European Federation for Soil Bioengineering, EFIB). The workshop revealed that this would require resources which potentially only larger scale projects can justify and that there would need to be an emphasis on supporting skills development of assessors and then, through its application, the framework can help promote learning amongst stakeholders. Incorporating ecoengineering sustainability measurement into the quality management systems of an organisation also ensures that those responsible for the measurement are identified and made accountable. Their role relating to the use of the framework should be clearly described to ensure their responsibility is understood. The assessment should be performed by personnel/organizations who can offer an unbiased opinion - either personnel from a separate part of the organization or from an external audit organization - in order to maintain reputation and improve internal processes.

\section{Conclusion}

- A sustainability assessment framework including relatively low number of eco-engineering sustainability KPI has been developed to benchmark the sustainability performance of eco-engineering measures.

- Attempting to cover socio-economic, environmental and engineering performance of an eco-engineering project, the framework can be used as part of the existing QA/QM procedures with a number of KPIs already being measured as part of the other QA processes.

- The developed framework can be used to assess the eco-engineering measure performance after the application. The graphical output of the assessment (Figure 3) makes the framework easier to uses also throughout each project stage as a planning and decision making tool.

- To improve the accuracy and applicability of the framework, it will need to be applied on projects in different bio-geo-climatic regions. This can be promoted by the professional organisations (e.g. EFIB) in order to achieve upskilling of the membership. 


\section{Acknowledgements}

We thank the staff at the Aberdeenshire Council Roads and Transportation Department, Jacobs Ground Engineering Department, Forkers Ltd, and Stonehaven and District Community Council for useful input and access to information. This study was partly funded by the Erasmus+ project ECOMED (575796-EPP-1-2016-1ES-EPPKA2-KA; www.ecomedbio.org).

\section{References}

Ahmed, M.D. and Sundaram, D. 2012. Sustainability modelling and reporting: from road map to implementation, Decision Support Systems, 53: 3, pp 611-624.

Boër, C.R., Pedrazzoli, P., Bettoni, A. and Sorlini, M., 2013. Sustainability Assessment Model. In Mass Customization and Sustainability (pp. 33-142). Springer London.

Bond A., Morrison-Saunders A., Pope J. 2012. Sustainability Assessment: the state of the art. Impact Assessment and Project Appraisal, 30(1), 53-62.

Braun, V. and Clarke, V. 2006. Using thematic analysis in psychology. Qualitative Research in Psychology, 3 (2). pp. 77-101.

Bromley, D. 1998. Searching for sustainability: the poverty of spontaneous order. Ecological economics, 24: 231-40.

Cole, R.J. and Valdebenito, M.J. 2013. The importation of building environmental certification systems: international usages of BREEAM and LEED. Building Research \& Information, 41(6), 662-676.

Cole, R.J. 2005. Building environmental assessment methods: Redefining intentions and roles. Building Research \& Information, 33(5), 455-467.

Costanza, R. and Patten, B.C. 1995. Defining and predicting sustainability. Ecological Economics 15: 193-196.

Currie, C., Murdoch, W., Sallis, D., and Smith, M. 2009. Forensic investigation of a failed road at Bervie Braes, Stonehaven - models and mechanisms. In: Forensic Engineering - From Failure to Understanding, B. Neale (ed.), Thomas Telford, London, 325-334.

ECTP reFINE. 2012. Research for Infrastructure Network in Europe) initiative - Building Up Infrastructure Networks of a Sustainable Europe - Strategic targets and expected impacts - ECTP. Retrieved from www. ectp.org.

El-Haram, M., Walton, J., Horner, M., Hardcastle, C., Price, A., Bebbington, J., Thomson, C., Atkin-Wright, T. 2007. Development of an integrated sustainability assessment toolkit, In: Horner, RMW, Hardcastle C, Price A, Bebbington J (Eds) Proceedings of the International Conference on Whole Life Urban Sustainability and its Assessment, Glasgow, 27-29 June 2007.

El-Haram, M.A., Horner, R.M.W., and Thomson, C.S., 2009. Developing an integrated assessment tool for urban environments, In Slaus I. (Ed) UNESCO Sponsored $8^{\text {th }}$ Dubrovnik Conference on Sustainable Development of Water and Environmental Systems, September 2009, Dubrovnik, Croatia. 
Gibson, R.B. 2012. Why sustainability assessment?. In Sustainability assessment: pluralism, practice and progress, 1st ed., Chapter 1 Edited by: Bond, A., Morrison-Saunders, A. and Howitt, R. London: Taylor \& Francis.

Jefferson, I., Hunt, D.V.L., Birchall, C.A. and Rogers C.D.F. 2007. Sustainability indicators for environmental geotechnics. Engineering Sustainability 160:2, 57-78.

Kucukvar, M and Tatari, O. 2013. Towards a triple bottom-line sustainability assessment of the U.S. construction industry. International Journal of Life Cycle Assessment, 18(5), 958-972.

Lim, S.K. 2009. Framework and processes for enhancing sustainability deliverables in Australian road infrastructure projects. $\mathrm{PhD}$ Thesis, Queensland University of Technology.

Mickovski, S.B. 2014. Resilient design of landslip prevention measures: a case study. Proceedings of the ICE - Forensic Engineering. 168(2):96-106. DOI: 10.1680/feng.14.00001

Mickovski, S.B. 2016. Why is the future ready for Environmental Geotechnics? Environmental Geotechnics. 3(2):63-64.

Mickovski, S.B. and van Beek, L.P.H. 2006. A decision support system for the evaluation of eco-engineering strategies for slope protection. Geotechnical \& Geological Engineering 24 (3), 483-498.

Mickovski, S.B., Black, J.D. and Smith, M.J. 2013. Innovative use of ECC (NEC3) for procurement and management of infrastructure projects with limited funding: Bervie Braes case study In: Smith, S.D and Ahiaga-Dagbui, D.D (Eds) Procs $29^{\text {th }}$ Annual ARCOM Conference, 2-4 September 2013, Reading, UK, Association of Researchers in Construction Management, 799-808.

Mitsch, W.J., Jørgensen, S.E. 2004. Ecological engineering and ecosystem restoration. Wiley, New York

Morrision-Saunders, A. and Pope, J. (2013) Conceptualising and managing trade-offs in sustainability assessment, Environmental Impact Assessment Review, 38(1), 54-63.

Norris, J.E., Stokes, A., Mickovski, S.B., Cammeraat, E., van Beek, R., Nicoll, B.C., Achim, A. (eds). 2008. Slope stability and erosion control: Ecotechnological solutions. Springer, The Netherlands

Pope, J., Annandale, D., and Morrison-Saunders, A. 2004 Conceptualising sustainability assessment, Environmental Impact Assessment Review, 24(6), 595-616.

Raudsepp-Hearne, C., Peterson, G.D., Tengö, M., Bennett, E.M., Holland, T., Benessaiah, K., MacDonald, G.M., Pfeifer, L. 2010. Untangling the Environmentalist's Paradox: Why is Human Well-Being Increasing as Ecosystem Services Degrade? BioScience 60 (8): 576-589.

Schiechtl, H.M. and Stern, R. 1996. Ground bioengineering techniques for slope protection and erosion control. Blackwell Science, Oxford, UK, 146pp.

Singh, R.K., Murty, H.R., Gupta, S.K. and Dikshit, A.K., 2012. An overview of sustainability assessment methodologies. Ecological Indicators, 15(1):.281-299.

Srdić, A. and Šelih, J., 2011. Integrated quality and sustainability assessment in construction: a conceptual model. Technological and economic development of economy, 17(4): 611-626.

Stokes, A., Sotir, R.B, Chen, W., Ghestem, M. 2010. Soil bio- and ecoengineering in China, past experience and present priorities. Ecol Eng 36:247-257

Stokes, A et al. 2014. Ecological mitigation of hillslope instability: ten key issues facing researchers and practitioners. Plant and Soil 377(1-2): 1-23. 
Studer, R and Zeh, H. 2014. Soil Bioengineering Construction Type Manual. Vdf Hochschulverlag AG, ETH Zurich, Switzerland, 440pp.

Swan, W. and Kyng, E. 2004. An introduction to Key Performance Indicators. Centre for Construction Innovation, Manchester, UK, 22pp.

Thomson, C.S., El-Haram, M.A. and Emmanuel, R. 2011 Managing sustainability assessment within the project lifecycle, Proceedings of ICE Engineering Sustainability, 164(2), 143-157

Thomson, C., Mickovski, S. and Orr, C. 2014. Promoting double loop learning in flood risk management in the Scottish context In: Raiden, A B and Aboagye-Nimo, E (Eds). Procs 30th Annual ARCOM Conference, 1-3 September 2014, Portsmouth, UK, Association of Researchers in Construction Management, 1185-1194.

Vaniček, I., Jirasko, D., and Vaniček, M. 2016. Added Value of Transportation Geotechnics to the Sustainability (Design Approach). Procedia Engineering 143:1417-1423.

Walton, J.S., El-Haram, M., Castillo, N.H., Horner, R.M.W., Price, A.D.F., Hardcastle, C. 2005. Integrated Assessment of Urban Sustainability. Proceedings of ICE - Engineering Sustainability, 158(2), 57-65.

Yin, R. K. (1994). Case study research: Design and methods (2nd ed.). Newbury Park, CA: Sage Publications, 170pp.

Zeng, S.X., Tam, C.M. and Tam, V.W. 2010. Integrating safety, environmental and quality risks for project management using a FMEA method. Engineering Economics, 21(1): 44-52. 
Table 1 Sustainability performance of the case study project during the Feasibility stage. Newly developed KPI shown in red.

\begin{tabular}{|c|c|c|c|c|c|c|}
\hline \multicolumn{2}{|l|}{ Phase A - Feasibility } & \multicolumn{3}{|c|}{ Effect on Sustainability } & \multirow[b]{2}{*}{ Significantly improved } & \multirow[b]{2}{*}{ Score } \\
\hline Indicator & Harmful & Reduction & Neutral & Improved & & \\
\hline $\begin{array}{l}\text { Does ther client have } \\
\text { a sustainable policy? }\end{array}$ & $\begin{array}{l}\text { Actively avoids } \\
\text { sustainability }\end{array}$ & $\begin{array}{c}\text { Passively avoids } \\
\text { sustainability }\end{array}$ & $\begin{array}{l}\text { No policy in } \\
\text { place }\end{array}$ & $\begin{array}{c}\text { Passively } \\
\text { promotes } \\
\text { sustainability }\end{array}$ & $\begin{array}{l}\text { Actively promotes } \\
\text { sustainability }\end{array}$ & 4 \\
\hline $\begin{array}{l}\text { Is there a community } \\
\text { consultation plan? }\end{array}$ & $\begin{array}{c}\text { Actively avoids } \\
\text { consultation }\end{array}$ & None & Basic & $\begin{array}{r}\text { Detailed using } \\
\text { single medium }\end{array}$ & $\begin{array}{c}\text { Detailed using multiple } \\
\text { media } \\
\end{array}$ & 5 \\
\hline $\begin{array}{c}\text { Does the site have } \\
\text { redevelopment } \\
\text { potential? }\end{array}$ & None & Very low & Low & High & Very high & 2 \\
\hline $\begin{array}{l}\text { Is the site suitable for } \\
\text { its future use? }\end{array}$ & Detrimental & $\begin{array}{l}\text { Questions } \\
\text { remain } \\
\text { unanswered }\end{array}$ & No effect & Yes & Very suitable & 2 \\
\hline $\begin{array}{c}\text { Percentage of site } \\
\text { investigation costs } \\
\text { against proposed } \\
\text { total cost }\end{array}$ & $<0.5 \%$ & $0.5-1.0 \%$ & $1.0-3.0 \%$ & $3.0-4.0 \%$ & $>5.0 \%$ & 2 \\
\hline Types of tests & No analysis & $\begin{array}{l}\text { Simple in situ } \\
\text { tests only }\end{array}$ & Lab tests only & Field trials only & Lab and field trials & 4 \\
\hline $\begin{array}{l}\text { Ecoengineering } \\
\text { sample spacing }\end{array}$ & $>100 \mathrm{~m}^{2}$ & $100-50 m^{2}$ & $50-20 m^{2}$ & $20-10 m^{2}$ & $<10 m^{2}$ & 3 \\
\hline $\begin{array}{l}\text { Ownership and land } \\
\text { use rights and } \\
\text { indemnities have } \\
\text { been clarified }\end{array}$ & Not clear & $\begin{array}{l}\text { Application for } \\
\text { land use rights } \\
\text { needed }\end{array}$ & Not applicable & $\begin{array}{l}\text { No issues } \\
\text { identified }\end{array}$ & $\begin{array}{l}\text { Assumption of risk, } \\
\text { waiver, and release of } \\
\text { liability and indemnity } \\
\text { agreed }\end{array}$ & 2 \\
\hline Total & & & & & & 3.4 \\
\hline
\end{tabular}


Table 2a Sustainability performance of the case study project during the Design stage. Generic KPIs.

\begin{tabular}{|c|c|c|c|c|c|c|}
\hline Phase B - Design & & & Effect on Sustainabilit & & & \\
\hline Indicator & Harmful & Reduction & Neutral & Improved & Significantly improved & Score \\
\hline $\begin{array}{l}\text { Land intended for use that } \\
\text { was previously unusable }\end{array}$ & $\begin{array}{l}\text { Land loss } \\
\text { increased }\end{array}$ & No change & Partial reuse of site & $\begin{array}{l}100 \% \text { but with no } \\
\text { recreational facilities }\end{array}$ & $\begin{array}{c}100 \% \text { of the site with some } \\
\text { recreational facilities }\end{array}$ & 5 \\
\hline $\begin{array}{l}\text { Land intended for use by } \\
\text { business and/or } \\
\text { infrastructure } \\
\text { (health/education/transport } \\
\text { ) that contributes to the local } \\
\text { economy }\end{array}$ & $\begin{array}{c}\text { No onflux of } \\
\text { new } \\
\text { business/infrast } \\
\text { ructure }\end{array}$ & $\begin{array}{c}<20 \% \text { of site } \\
\text { allocated to new } \\
\text { business/infrastruct } \\
\text { ure }\end{array}$ & $\begin{array}{c}20 \%-50 \% \text { of site } \\
\text { allocated to new } \\
\text { business/infrastructure }\end{array}$ & $\begin{array}{c}\text { Majority of site } \\
\text { allocated to new } \\
\text { business/infrastructure }\end{array}$ & $\begin{array}{l}\text { Whole site allocated to new } \\
\text { business/infrastructure }\end{array}$ & 2 \\
\hline $\begin{array}{l}\text { Quantified Risk Assessment } \\
\qquad \text { (QRA) }\end{array}$ & $\begin{array}{l}\text { No attempt at } \\
\text { producing a QRA }\end{array}$ & $\begin{array}{l}\text { Partial QRA that } \\
\text { does not cover all } \\
\text { aspects of the site }\end{array}$ & $\begin{array}{l}\text { Full QRA, office based } \\
\text { without ability to } \\
\text { procure further testing }\end{array}$ & $\begin{array}{l}\text { Full QRA, office based } \\
\text { with ability to procure } \\
\text { furthter testing }\end{array}$ & $\begin{array}{l}\text { Full QRA linked with field } \\
\text { trial programme }\end{array}$ & 4 \\
\hline $\begin{array}{c}\text { Has the design followed a } \\
\text { defined risk management } \\
\text { plan? }\end{array}$ & None devised & $\begin{array}{c}\text { Partial plan devised } \\
\text { covering aspects of } \\
\text { the project }\end{array}$ & $\begin{array}{c}\text { Initial risk management } \\
\text { plan devised }\end{array}$ & $\begin{array}{l}\text { Integral assessment } \\
\text { devised covering most } \\
\text { aspects of the project }\end{array}$ & $\begin{array}{c}\text { Full integral assessment } \\
\text { devised covering all aspects } \\
\text { of the project }\end{array}$ & 4 \\
\hline $\begin{array}{l}\text { Is there a Health and Safety } \\
\text { (H\&S) plan agreed? }\end{array}$ & $\begin{array}{c}\text { Company has no } \\
\text { H\&S policy }\end{array}$ & $\begin{array}{c}\text { Company has H\&S } \\
\text { policy but no plan } \\
\text { instigated }\end{array}$ & $\begin{array}{l}\text { Company has H\&S } \\
\text { policy but plan only } \\
\text { covers the most } \\
\text { dangerous aspects }\end{array}$ & $\begin{array}{c}\text { Company has H\&S policy } \\
\text { and plan drawn up by a } \\
\text { non-dedicated H\&S } \\
\text { employee covering all } \\
\text { aspects } \\
\end{array}$ & $\begin{array}{l}\text { Full plan devised by } \\
\text { dedicated H\&S employee } \\
\text { covering all aspects }\end{array}$ & 5 \\
\hline $\begin{array}{l}\text { Will theH\&S plan meet } \\
\text { national environmental } \\
\text { regulatory guidelines? }\end{array}$ & No & $\begin{array}{l}\text { Yes with minor } \\
\text { alteration }\end{array}$ & Yes with modification & $\begin{array}{l}\text { Yes with minor } \\
\text { alteration }\end{array}$ & Yes & 4 \\
\hline $\begin{array}{c}\text { Has a life cycle assessment } \\
\text { been done? }\end{array}$ & None devised & No category & Partial reuse of site & No category & Yes & 1 \\
\hline $\begin{array}{l}\text { Has a sustainability option } \\
\text { appraisal been done? }\end{array}$ & $\begin{array}{l}\text { No awareness } \\
\text { of sustainability } \\
\text { option appraisal } \\
\text { techniques }\end{array}$ & $\begin{array}{c}\text { No formal appraisal } \\
\text { but aware of } \\
\text { sustainability }\end{array}$ & $\begin{array}{l}\text { Yes covering the } \\
\text { minority of aspects }\end{array}$ & $\begin{array}{l}\text { Yes covering the } \\
\text { majority of aspects }\end{array}$ & $\begin{array}{c}\text { Yes covering all aspects of } \\
\text { the project }\end{array}$ & 4 \\
\hline $\begin{array}{c}\text { Biodiversity/habitat creation } \\
\text { assessment with appropriate } \\
\text { mitigation } \\
\end{array}$ & $\begin{array}{l}\text { Harmful to } \\
\text { biodiversity }\end{array}$ & $\begin{array}{l}\text { No assessment } \\
\text { carrie dout }\end{array}$ & Assessed and no effect & May aid improvement & $\begin{array}{l}\text { Contributes to improving } \\
\text { biodiversity }\end{array}$ & 4 \\
\hline $\begin{array}{l}\text { Establishment of the design } \\
\text { team at an early stage }\end{array}$ & $\begin{array}{c}\text { No necessary } \\
\text { party involved } \\
\text { early }\end{array}$ & $\begin{array}{c}\text { One necessary party } \\
\text { involved early }\end{array}$ & $\begin{array}{c}\text { Two necessary parties } \\
\text { involved early }\end{array}$ & $\begin{array}{l}\text { More than two } \\
\text { necessary parties } \\
\text { involved early }\end{array}$ & $\begin{array}{l}\text { All necessary parties } \\
\text { involved early }\end{array}$ & 4 \\
\hline $\begin{array}{c}\text { Percentage of supplies } \\
\text { specified from sustainable } \\
\text { sources or recycled material }\end{array}$ & $<20 \%$ & $20-30 \%$ & $30-40 \%$ & $40-50 \%$ & $>50 \%$ & 1 \\
\hline $\begin{array}{l}\text { Does the design assess } \\
\text { whole life costs? }\end{array}$ & No & $\begin{array}{c}\text { Costs accounted for } \\
\text { until the end of } \\
\text { contractors } \\
\text { warranty }\end{array}$ & $\begin{array}{l}\text { Internal assessment by } \\
\text { untrained designer }\end{array}$ & $\begin{array}{l}\text { Internal assessment by } \\
\text { trained designer }\end{array}$ & $\begin{array}{l}\text { Yes, using a recognised } \\
\text { sustainability tool (e.g. } \\
\text { BREEAM; CEEQUAL) }\end{array}$ & 1 \\
\hline
\end{tabular}


Table $2 \mathrm{~b}$ Sustainability performance of the case study project during the Design stage. Technique specific newly developed KPI shown in red.

\begin{tabular}{|c|c|c|c|c|c|c|}
\hline \multicolumn{7}{|c|}{ Technique specific Stage B (Design) indicators } \\
\hline $\begin{array}{l}\text { Intended primary use of } \\
\text { vegetation in the design }\end{array}$ & None & No category & Landscaping/aesthetics & No category & Multi-engineering purposes & 5 \\
\hline $\begin{array}{c}\text { Has the design team been } \\
\text { trained in ecoengineering } \\
\text { (sustainable use of } \\
\text { vegetation)? }\end{array}$ & $\begin{array}{l}\text { None of the } \\
\text { team }\end{array}$ & $\begin{array}{l}\text { Minority of the } \\
\text { team }\end{array}$ & Half of the team & Majority of the team & All of the team & 1 \\
\hline $\begin{array}{l}\text { Have topographical maps, } \\
\text { surveys, and aerial photos } \\
\text { been obtained for the site? }\end{array}$ & None & No category & Partially & No category & Full record & 5 \\
\hline $\begin{array}{c}\text { Have the geological and } \\
\text { hydrogeological } \\
\text { investigations been carried } \\
\text { out and evaluated? } \\
\end{array}$ & $\begin{array}{l}\text { Report based on } \\
\text { a site walkover }\end{array}$ & $\begin{array}{c}\text { Desk study based on } \\
\text { assumed or simple } \\
\text { in-situ derived } \\
\text { parameters }\end{array}$ & $\begin{array}{c}\text { Modelling study based } \\
\text { on either laboratory or } \\
\text { assumed parameters }\end{array}$ & $\begin{array}{l}\text { GIR or Hydrogeology } \\
\text { report/study based on } \\
\text { lab and in situ testing }\end{array}$ & $\begin{array}{l}\text { GIR and Hydrogeology } \\
\text { reports/studies including } \\
\text { soil-water relationships }\end{array}$ & 5 \\
\hline $\begin{array}{c}\text { Have the pedological } \\
\text { investigations been carried } \\
\text { out and evaluated? }\end{array}$ & None & Based on literature & $\begin{array}{c}\text { Based on partial survey } \\
\text { on site }\end{array}$ & Full site survey & Pedological study & 1 \\
\hline $\begin{array}{l}\text { Have vegetation survey and } \\
\text { mapping been carried out } \\
\text { for the site and the } \\
\text { surrounding area? }\end{array}$ & Site walkover & Partial survey & Full survey & $\begin{array}{l}\text { Full survey and mapping } \\
\text { without rooting } \\
\text { characteristics }\end{array}$ & $\begin{array}{l}\text { Full survey and mapping } \\
\text { including rooting } \\
\text { characteristics of the } \\
\text { established vegetative cover }\end{array}$ & 4 \\
\hline $\begin{array}{l}\text { Has ecological data been } \\
\text { collected and interpreted? }\end{array}$ & Site walkover & Partial survey & Full factual survey & $\begin{array}{c}\text { Full survey and mapping } \\
\text { without imact } \\
\text { assessment }\end{array}$ & $\begin{array}{c}\text { Full environmental impact } \\
\text { statement }\end{array}$ & 3 \\
\hline $\begin{array}{c}\text { Has the cause of damage (in } \\
\text { case fo repair works) or } \\
\text { potential failure mechanism } \\
\text { (in case of new built) been } \\
\text { investigated? }\end{array}$ & $\begin{array}{c}\text { Expert } \\
\text { judgement used }\end{array}$ & $\begin{array}{l}\text { Desk study based on } \\
\text { assumed or simple } \\
\text { in-situ derived } \\
\text { parameters }\end{array}$ & $\begin{array}{l}\text { Modelling study based } \\
\text { on either laboratory or } \\
\text { assumed parameters }\end{array}$ & $\begin{array}{l}\text { Stability analysis base } \\
\text { don lab and in situ } \\
\text { testing }\end{array}$ & $\begin{array}{c}\text { Full stability analysis in } \\
\text { accordance to Eurcode } 7 \\
\text { including Geotechnical } \\
\text { Design Report }\end{array}$ & 4 \\
\hline $\begin{array}{l}\text { Has the target to be } \\
\text { achieved by the proposed } \\
\text { measures been determined? }\end{array}$ & $\begin{array}{l}\text { No target } \\
\text { specified }\end{array}$ & No category & $\begin{array}{c}\text { Target determined but } \\
\text { not justified or } \\
\text { incorporated in project } \\
\text { outputs }\end{array}$ & No category & $\begin{array}{l}\text { Target quantified and } \\
\text { incorporated in project } \\
\text { outputs }\end{array}$ & 1 \\
\hline $\begin{array}{c}\text { Have the type of } \\
\text { plant/material and } \\
\text { construction type/method to } \\
\text { be used been } \\
\text { selected/specified? }\end{array}$ & No specification & No category & $\begin{array}{l}\text { Modified specification } \\
\text { (e.g. earthworks) }\end{array}$ & No category & $\begin{array}{l}\text { Separate ecoengineering } \\
\text { specification }\end{array}$ & 3 \\
\hline $\begin{array}{l}\text { How many of the groups } \\
\text { below are to be used: a) } \\
\text { seeds of grasses, herbs, } \\
\text { trees, shrubs; b) parts of } \\
\text { woody plants capable of } \\
\text { propagation; c) parts of } \\
\text { herbs and grasses suitable } \\
\text { for propagation; d) saplings } \\
\text { and rooted shrubs; e) turf, } \\
\text { sods incl. topsoiland } \\
\text { vegetative cover? } \\
\end{array}$ & 1 of 5 & 2 of 5 & 3 of 5 & 4 of 5 & 5 of 5 & 3 \\
\hline $\begin{array}{c}\text { Origin of plant material } \\
\text { specified }\end{array}$ & $\begin{array}{l}\text { Non-native } \\
\text { vegetation }\end{array}$ & $\begin{array}{l}\text { Native vegetation } \\
\text { imported from off } \\
\text { site }\end{array}$ & In situ vegetation & $\begin{array}{l}\text { In situ vegetation } \\
\text { removed before } \\
\text { construction, stored } \\
\text { during construction } \\
\end{array}$ & $\begin{array}{l}\text { Native and indigenous, } \\
\text { including in situ vegetation } \\
\text { removed and stored }\end{array}$ & 5 \\
\hline $\begin{array}{l}\text { Biotechnical character of } \\
\text { specified vegetation: a) root- } \\
\text { in capability; b) resistance to } \\
\text { mechanical forces; c) soil } \\
\text { binding capacity; d) soil } \\
\text { improvement capacity; e) } \\
\text { salt tolerance }\end{array}$ & 1 of 5 & 2 of 5 & 3 of 5 & 4 of 5 & 5 of 5 & 1 \\
\hline Seed selection & None & Monoculture & Standard seed mix & $\begin{array}{l}\text { Certified by external } \\
\text { organisation }\end{array}$ & $\begin{array}{l}\text { Tested in specialist } \\
\text { laboratory with regard to } \\
\text { suitability and quality }\end{array}$ & 4 \\
\hline $\begin{array}{c}\text { Use of woody plants with } \\
\text { adventitious buds (live } \\
\text { cuttings, branches, stems, } \\
\text { poles) }\end{array}$ & $\begin{array}{c}\text { No } \\
\text { selection/use }\end{array}$ & No category & $0-10 \mathrm{~mm}$ thick & No category & $10-80 \mathrm{~mm}$ thick & \\
\hline Source of planting materials & Nursery $>20 \mathrm{~km}$ & No category & $\begin{array}{l}\text { Adjacent nearby } \\
\text { ecologically similar } \\
\text { woodland or nursery }\end{array}$ & No category & $\begin{array}{l}\text { Thinning and prunning of } \\
\text { established nearby } \\
\text { protection works planted } \\
\text { with suitable species }\end{array}$ & 1 \\
\hline $\begin{array}{l}\text { Timing for obtaining } \\
\text { cuttings/poles }\end{array}$ & Not considered & $\begin{array}{c}\text { Considered and } \\
\text { discarded }\end{array}$ & $\begin{array}{c}\text { Considered but no } \\
\text { choice }\end{array}$ & August to June & October to April & \\
\hline $\begin{array}{l}\text { Timing between plant } \\
\text { collection and planting }\end{array}$ & $\begin{array}{c}\begin{array}{c}\text { Shoots thrown } \\
\text { off plant } \\
\text { material }\end{array} \\
\end{array}$ & $\begin{array}{c}\begin{array}{c}\text { Preserved but not } \\
\text { protected against } \\
\text { drying and bacterial } \\
\text { heating }\end{array} \\
\end{array}$ & $\begin{array}{c}\text { Preserved and } \\
\text { protected against } \\
\text { drying and bacterial } \\
\text { heating } \\
\end{array}$ & $2-10$ days & $0-2$ days & 2 \\
\hline $\begin{array}{l}\text { Preserving of topsoil from } \\
\text { site clearance and flattening } \\
\text { of the slopes }\end{array}$ & $\begin{array}{l}\text { Disposed off } \\
\text { site }\end{array}$ & $\begin{array}{c}\text { Deposited } \\
\text { elesewhere on site }\end{array}$ & Used for landscaping & $\begin{array}{c}\text { Used as part of } \\
\text { temporary or } \\
\text { permanent } \\
\text { ecoengineering works }\end{array}$ & $\begin{array}{l}\text { Used as part of temporary } \\
\text { and permanent } \\
\text { econegineering works }\end{array}$ & 2 \\
\hline Design optimisation & Not considered & $\begin{array}{l}\text { Optimised for cost } \\
\text { only }\end{array}$ & $\begin{array}{l}\text { Optimised for cost and } \\
\text { labour (time) }\end{array}$ & $\begin{array}{l}\text { Optimised for cost, } \\
\text { time, and incorporation } \\
\text { of vegetation for } \\
\text { engineering function }\end{array}$ & $\begin{array}{c}\text { Demonstrated by a cost- } \\
\text { benefit analysis comparing } \\
\text { the proposed } \\
\text { ecoengineering vs relevant } \\
\text { 'hard' solution in terms of } \\
\text { sustainability }\end{array}$ & 2 \\
\hline Total & & & & & & 3.0 \\
\hline
\end{tabular}


Table 3 Sustainability performance of the case study project during the Award stage.

\begin{tabular}{|c|c|c|c|c|c|c|}
\hline Phase C-Award & & & Effect on Sustainability & & & \\
\hline Indicator & Harmful & Reduction & Neutral & Improved & Significantly improved & Score \\
\hline Type of procurement & $\begin{array}{c}\text { Lowest-cost } \\
\text { competitive tender }\end{array}$ & Negotiated contract & Pre-qualification list & $\begin{array}{c}\text { Contrator/subcontractor } \\
\text { partnership }\end{array}$ & Public-private partnership & 3 \\
\hline $\begin{array}{c}\text { At what stage does the } \\
\text { specialist remediation } \\
\text { contractor become involved in } \\
\text { the design? }\end{array}$ & No input & $\begin{array}{l}\text { Tender stage with more } \\
\text { than } 1 \text { month befor } \\
\text { esubmission }\end{array}$ & $\begin{array}{l}\text { Concurrently with the } \\
\text { main contractor }\end{array}$ & $\begin{array}{l}\text { Pre-detailed design in } \\
\text { consultation with the } \\
\text { client's engineer }\end{array}$ & $\begin{array}{l}\text { Pre-detailed design in } \\
\text { partnership with the } \\
\text { engineer }\end{array}$ & 1 \\
\hline $\begin{array}{c}\text { Does the contractor have } \\
\text { ISO14001 or formal } \\
\text { environmental mgmt. system }\end{array}$ & No & Undergoing accreditation & $\begin{array}{l}\text { A minority of business } \\
\text { units are accredited }\end{array}$ & $\begin{array}{l}\text { The majority of business } \\
\text { units are accredited }\end{array}$ & $\begin{array}{l}\text { All business units are } \\
\text { accredited }\end{array}$ & 5 \\
\hline $\begin{array}{c}\text { Percentage of sub-contract } \\
\text { supply by value from ISO } 14001 \\
\text { accredited suppliers } \\
\end{array}$ & $<10 \%$ & $10-20 \%$ & $20-35 \%$ & $35-50 \%$ & $>50 \%$ & 5 \\
\hline $\begin{array}{l}\text { Does the contractor have } \\
\text { Investors in People } \\
\text { accreditation? }\end{array}$ & No & Undergoing accreditation & $\begin{array}{l}\text { A minority of business } \\
\text { units are accredited }\end{array}$ & $\begin{array}{l}\text { The majority of business } \\
\text { units are accredited }\end{array}$ & $\begin{array}{c}\text { All business units are } \\
\text { accredited }\end{array}$ & 5 \\
\hline $\begin{array}{l}\text { Percentage of sub-contract } \\
\text { supply by value from Investors } \\
\text { in People accredited suppliers }\end{array}$ & $<10 \%$ & $10-20 \%$ & $20-35 \%$ & $35-50 \%$ & $>50 \%$ & 3 \\
\hline $\begin{array}{c}\text { Has the contractor had any } \\
\text { formal nuisance notices } \\
\text { served? }\end{array}$ & $>1$ in last 3 years & 1 in last 3 years & 1 in last 5 years & $\begin{array}{l}1 \text { prior to ISO } 14001 \\
\quad \text { certification }\end{array}$ & Never & 3 \\
\hline $\begin{array}{l}\text { Safety record by reportable } \\
\text { incidents }\end{array}$ & $\begin{array}{l}25 \% \text { higher than the } \\
\text { sector average }\end{array}$ & $\begin{array}{c}50 \% \text { higher than the sector } \\
\text { average }\end{array}$ & $\begin{array}{c}25 \% \text { higher than the sector } \\
\text { average }\end{array}$ & $\begin{array}{c}25 \% \text { lower than the } \\
\text { sector average }\end{array}$ & $\begin{array}{c}50 \% \text { lower than the sector } \\
\text { average }\end{array}$ & 5 \\
\hline $\begin{array}{l}\text { Does the contractor carry out } \\
\text { internal evaluation using KPIs? }\end{array}$ & $\begin{array}{l}\text { Never implemented } \\
\text { KPIs }\end{array}$ & Developing a KPI system & $\begin{array}{c}\text { A minority of business } \\
\text { units use KPIs }\end{array}$ & $\begin{array}{c}\text { The majority of business } \\
\text { units use KPIs }\end{array}$ & All business units use KPIs & 4 \\
\hline $\begin{array}{l}\text { Does the contractor produce } \\
\text { formal reports for } \\
\text { stakeholders }\end{array}$ & No & $\begin{array}{l}\text { Irregular social or } \\
\text { environmental } \\
\text { performance reports }\end{array}$ & $\begin{array}{l}\text { Irregular social and } \\
\text { environmental } \\
\text { performance reports }\end{array}$ & $\begin{array}{c}\text { Annual social or } \\
\text { environmental } \\
\text { performance reports }\end{array}$ & $\begin{array}{c}\text { Annual social and } \\
\text { environmental performance } \\
\text { reports }\end{array}$ & 5 \\
\hline $\begin{array}{l}\text { What percentage of } \\
\text { employees undergo } \\
\text { awareness training? }\end{array}$ & $<10 \%$ & $10-50 \%$ & $50-75 \%$ & $75-100 \%$ & $100 \%$ & 4 \\
\hline $\begin{array}{l}\text { Does the contractor have a } \\
\text { quality management system, } \\
\text { e.g. ISO9001? }\end{array}$ & No & Undergoing accreditation & $\begin{array}{l}\text { A minority of business } \\
\text { units are accredited }\end{array}$ & $\begin{array}{l}\text { The majority of business } \\
\text { units are accredited }\end{array}$ & $\begin{array}{l}\text { All business units are } \\
\text { accredited }\end{array}$ & 5 \\
\hline $\begin{array}{r}\text { Total } \\
\end{array}$ & & & & & & 4.0 \\
\hline
\end{tabular}


Table 4 Sustainability performance of the case study project during the Mobilisation stage.

\begin{tabular}{|c|c|c|c|c|c|c|}
\hline Stage D - Mobilisation & & & Effect on Sustainability & & & \\
\hline Indicator & Harmful & Reduction & Neutral & Improved & Significantly improved & Score \\
\hline How much plant is needed? & $\begin{array}{c}\text { Plant mobilised that is not } \\
\text { for contingency and never } \\
\text { used }\end{array}$ & $\begin{array}{c}\text { Plant held in } \\
\text { contingency but never } \\
\text { used }\end{array}$ & $\begin{array}{c}\text { Minimum plant held in } \\
\text { contingency but eventually } \\
\text { used } \\
\end{array}$ & $\begin{array}{l}\text { All plant used at some } \\
\text { stage on site }\end{array}$ & $\begin{array}{l}\text { All plant used } 100 \% \text { of the } \\
\text { time on site }\end{array}$ & 4 \\
\hline $\begin{array}{c}\text { Have all deliveries (plant } \\
\text { and materials) been chosen } \\
\text { to minimise access } \\
\text { disruptions? }\end{array}$ & $\begin{array}{l}\text { Multiple access routes that } \\
\text { do not avoid resiential areas }\end{array}$ & $\begin{array}{l}\text { Single access route } \\
\text { created that does not } \\
\text { avoid residential areas }\end{array}$ & $\begin{array}{c}\text { All deliveries use single } \\
\text { existing access route but } \\
\text { do not avoid residential } \\
\text { areas }\end{array}$ & $\begin{array}{l}\text { Single new access route } \\
\text { created that avoids } \\
\text { residential areas }\end{array}$ & $\begin{array}{l}\text { All deliveries use single } \\
\text { existing access route and } \\
\text { avoid residential areas }\end{array}$ & 1 \\
\hline Ingress and egress & $\begin{array}{l}\text { Road closures necessary to } \\
\text { crane plant onto site }\end{array}$ & $\begin{array}{c}\text { No traffic } \\
\text { management system }\end{array}$ & $\begin{array}{c}\text { Traffic management } \\
\text { system in place with } \\
\text { noticeable controlled } \\
\text { disruption }\end{array}$ & $\begin{array}{l}\text { Traffic management } \\
\text { system in place with } \\
\text { minor controlled } \\
\text { disruption }\end{array}$ & $\begin{array}{c}\text { Traffic management system } \\
\text { with no disruption and road } \\
\text { cleaning scheme in effect }\end{array}$ & 4 \\
\hline Transportation & $\begin{array}{l}\text { Plant mobilised from } \\
\text { storage }(>60 \mathrm{~km})\end{array}$ & $\begin{array}{l}\text { Plant mobilised form } \\
\text { storage }(<60 \mathrm{~km})\end{array}$ & $\begin{array}{c}\begin{array}{c}\text { Plant brought direct from } \\
\text { othe rpoject nationally } \\
(>60 \mathrm{~km})\end{array} \\
\end{array}$ & $\begin{array}{c}\text { Plant brought directly } \\
\text { form other project locally } \\
(<60 \mathrm{~km})\end{array}$ & Plant hired from local firm & 3 \\
\hline Labour & No local labour employed & $\begin{array}{l}<10 \% \text { of workforce is } \\
\text { local (within } 30 \mathrm{~km} \text { ) }\end{array}$ & $\begin{array}{c}10-25 \% \text { of workforce is } \\
\text { local }(<30 \mathrm{~km})\end{array}$ & $\begin{array}{c}25-50 \% \text { of workforce is } \\
\text { local }(<30 \mathrm{~km})\end{array}$ & $\begin{array}{c}>50 \% \text { of workforce is local } \\
(<30 \mathrm{~km})\end{array}$ & 1 \\
\hline $\begin{array}{c}\text { Percentage of materials (by } \\
\text { volume) delivered from } \\
\text { sustainable sources of } \\
\text { recycled material }\end{array}$ & $<20 \%$ & $20-30 \%$ & $30-40 \%$ & $40-50 \%$ & $>50 \%$ & 1 \\
\hline Materials sourced locally & $<20 \%$ & $20-30 \%$ & $30-40 \%$ & $40-50 \%$ & $>50 \%$ & 1 \\
\hline Total & & & & & & 2.1 \\
\hline
\end{tabular}


Table 5 Sustainability performance of the case study project during the Construction stage. Newly developed KPI shown in red.

\begin{tabular}{|c|c|c|c|c|c|c|}
\hline \multirow{2}{*}{$\frac{\text { Stage E - Construction }}{\text { Indicator }}$} & \multicolumn{4}{|c|}{ Effect on Sustainability } & \multirow[b]{2}{*}{ Significantly improved } & \multirow[b]{2}{*}{ Score } \\
\hline & Harmful & Reduction & Neutral & Improved & & \\
\hline $\begin{array}{l}\text { What percentage of } \\
\text { materials are disposed of in } \\
\text { relation to materials } \\
\text { supplied? }\end{array}$ & $>30 \%$ & $30-15 \%$ & $15-10 \%$ & $10-5 \%$ & $<5 \%$ & 5 \\
\hline $\begin{array}{c}\text { Have renewable energy } \\
\text { systems been used on site? }\end{array}$ & None & $\begin{array}{c}\text { Considered and } \\
\text { ignored }\end{array}$ & $\begin{array}{c}\text { Considered but not } \\
\text { practical }\end{array}$ & Minor usage & Significant usage & 1 \\
\hline $\begin{array}{l}\text { Is use of mains water } \\
\text { reduced? }\end{array}$ & $\begin{array}{l}\text { No restrictions on } \\
\text { mains water }\end{array}$ & $\begin{array}{l}\text { Mains water with } \\
\text { usage control }\end{array}$ & $\begin{array}{l}\text { Grey wate rused - no } \\
\text { resuse pf process water }\end{array}$ & $\begin{array}{c}\text { Process water reused } \\
\text { in combination with } \\
\text { mains water }\end{array}$ & $\begin{array}{c}\text { Process water reused in } \\
\text { combination of grey } \\
\text { water }\end{array}$ & 3 \\
\hline $\begin{array}{l}\text { Is there a dust suppression } \\
\text { plan? }\end{array}$ & No & $\begin{array}{l}\text { Plan to reduce dust } \\
\text { creation }\end{array}$ & $\begin{array}{l}\text { Water spray dampeners } \\
\text { using mains water }\end{array}$ & $\begin{array}{c}\text { Water spray } \\
\begin{array}{c}\text { dampeners using grey } \\
\text { water }\end{array} \\
\end{array}$ & $\begin{array}{c}\text { Integrated dust } \\
\text { prevention plan } \\
\text { implemented } \\
\end{array}$ & 1 \\
\hline Fossil fuel usage & $\begin{array}{c}\text { No restrictions in } \\
\text { usage }\end{array}$ & $\begin{array}{l}\text { Limited by awareness } \\
\text { training }\end{array}$ & Minimised by action plan & $\begin{array}{l}\text { Some replaced by } \\
\text { alternatives }\end{array}$ & $\begin{array}{l}\text { All fossil fuel changed to } \\
\text { alternative power sources }\end{array}$ & 2 \\
\hline $\begin{array}{c}\text { Calculation of } \mathrm{CO}_{2} \text { emissions } \\
\text { and embodied energy (EE) }\end{array}$ & Not considered & $\begin{array}{c}\text { Considred but not } \\
\text { undertaken }\end{array}$ & $\begin{array}{l}\text { Partial analysis for either } \\
\mathrm{CO} 2 \text { or } \mathrm{EE}\end{array}$ & $\begin{array}{c}\text { Partial analysis for } \mathrm{CO} 2 \\
\text { and } \mathrm{EE}\end{array}$ & $\begin{array}{l}\text { Full analysis for } \mathrm{CO} 2 \text { and } \\
\text { EE }\end{array}$ & 3 \\
\hline Air quality: $\mathrm{SO}_{2}$ and $\mathrm{NO}_{x}$ & $\begin{array}{c}\begin{array}{c}\text { Only coal/oil used on } \\
\text { site }\end{array} \\
\end{array}$ & $\begin{array}{c}\text { Major coal/oil ratio to } \\
\text { gas }\end{array}$ & Equal coal/oil ratio to gas & $\begin{array}{c}\begin{array}{c}\text { Minor coal/oil ratio to } \\
\text { gas }\end{array} \\
\end{array}$ & $\begin{array}{c}\begin{array}{c}\text { Clean technology used } \\
\text { (solar etc) }\end{array} \\
\end{array}$ & 2 \\
\hline Air quality: ozone & $\begin{array}{l}\text { VOCs and } \mathrm{NO}_{\mathrm{x}} \\
\text { allowed to combine }\end{array}$ & No action & No category & $\begin{array}{l}\text { Prevention plan to } \\
\text { minimise and separate } \\
\mathrm{NO}_{x} \text { and VOCs }\end{array}$ & $\begin{array}{l}\text { No VOCs allowed into the } \\
\text { atmosphere on site }\end{array}$ & 1 \\
\hline Air quality: particulate & $\begin{array}{c}\text { No plant fitted with } \\
\text { particulate filter }\end{array}$ & $\begin{array}{c}\text { Minority of plant fitted } \\
\text { with particulate filter }\end{array}$ & Even split & $\begin{array}{l}\text { Most plant fitted with } \\
\text { particulate filter }\end{array}$ & $\begin{array}{l}\text { All plant fitted with } \\
\text { particulate filter }\end{array}$ & 4 \\
\hline Obstruction of light by smoke & $>10 \%$ of on-site time & $10-5 \%$ of on-site time & $5-1 \%$ of on-site time & $<1 \%$ of on-site time & $\begin{array}{c}\text { No visible smoke } \\
\text { produced }\end{array}$ & 5 \\
\hline $\begin{array}{c}\text { Is there a noise prevention } \\
\text { plan? }\end{array}$ & Noise issues ignored & $\begin{array}{l}\text { Awareness of noise } \\
\text { issues }\end{array}$ & Site curfews in force & $\begin{array}{l}\text { All plant treated with } \\
\text { noise control measures }\end{array}$ & $\begin{array}{c}\text { Integrated noise } \\
\text { prevention plan } \\
\text { implemented } \\
\end{array}$ & 3 \\
\hline $\begin{array}{l}\text { Are all items of 'wet' plant } \\
\text { (e.g. fuel bowser) properly } \\
\text { protected against spills? }\end{array}$ & No bunds on site & $\begin{array}{l}\text { Some protection in } \\
\text { place }\end{array}$ & Static plant protected & $\begin{array}{c}\text { Majority of plant } \\
\text { protected from leaks }\end{array}$ & $\begin{array}{l}\text { All 'wet' plant protected } \\
\text { from leak }\end{array}$ & 4 \\
\hline $\begin{array}{l}\text { Has the site supervisor } \\
\text { actively worked to reduce } \\
\text { movements? }\end{array}$ & No restrictions & $\begin{array}{l}\text { Plan in place but not } \\
\text { fully implemented }\end{array}$ & $\begin{array}{l}\text { On-site movements } \\
\text { minimised }\end{array}$ & $\begin{array}{l}\text { Deliveries to site } \\
\text { eminimised }\end{array}$ & $\begin{array}{l}\text { All traffic movements } \\
\text { assessed and minimised }\end{array}$ & 3 \\
\hline $\begin{array}{l}\text { Local community services } \\
\text { disruption }\end{array}$ & $\begin{array}{l}\text { Major utility lost on } \\
\text { more than one } \\
\text { occasion due to site } \\
\text { activity }\end{array}$ & $\begin{array}{l}\text { Major utility lost on } \\
\text { one occasion due to } \\
\text { site activity }\end{array}$ & $\begin{array}{l}\text { No services disrupted by } \\
\text { default }\end{array}$ & $\begin{array}{l}\text { Major utility unable to } \\
\text { be maintained but } \\
\text { community informed } \\
\text { of disruption and } \\
\text { compensated } \\
\end{array}$ & $\begin{array}{l}\text { Planned action taken to } \\
\text { not disrupt any services }\end{array}$ & 5 \\
\hline $\begin{array}{l}\text { Is any time lost due to } \\
\text { regulatory restrictions being } \\
\text { imposed? }\end{array}$ & $\begin{array}{l}\text { Site closed } \\
\text { temporarily and a } \\
\text { fine is issued }\end{array}$ & $\begin{array}{l}\text { Site closed temporarily } \\
\text { with no fines issued }\end{array}$ & $\begin{array}{l}\text { Warning provided and } \\
\text { acted on immediately }\end{array}$ & No restrictions & $\begin{array}{c}\text { No restrictions and } \\
\text { debrief provided for } \\
\text { feedback at end of the } \\
\text { project }\end{array}$ & 4 \\
\hline Plant washing facilities & No plant washing & $\begin{array}{c}\text { Plant washing using } \\
\text { mains water and non- } \\
\text { biodegradable } \\
\text { detergents } \\
\end{array}$ & $\begin{array}{c}\text { Plant washing using mains } \\
\text { water and biodegradable } \\
\text { detergents }\end{array}$ & $\begin{array}{c}\text { Plant washing with } \\
\text { grey water system and } \\
\text { biodegradable } \\
\text { detergents }\end{array}$ & $\begin{array}{c}\text { Plant washing with grey } \\
\text { water recycling system } \\
\text { and no detergents }\end{array}$ & 4 \\
\hline \multicolumn{7}{|c|}{ Technique specific stage E construction indicators } \\
\hline $\begin{array}{l}\text { Preliminary works for } \\
\text { protection of the site and } \\
\text { safety of the workforce }\end{array}$ & $\begin{array}{l}\text { Preliminary works } \\
\text { including heavy } \\
\text { machinery only }\end{array}$ & $\begin{array}{c}\text { Preliminary works } \\
\text { carried out prior to the } \\
\text { start of the } \\
\text { construction only } \\
\end{array}$ & $\begin{array}{c}\text { Preliminary works } \\
\text { specified but not detailed }\end{array}$ & $\begin{array}{c}\text { Preliminary works } \\
\text { phased to precede } \\
\text { each construction stage }\end{array}$ & $\begin{array}{c}\text { Preliminary works } \\
\text { planned for minimum site } \\
\begin{array}{c}\text { (soil and vegetation) } \\
\text { disturbance }\end{array}\end{array}$ & 2 \\
\hline Temporary works (support) & $\begin{array}{l}\text { "Hard' techniques } \\
\text { used only for short } \\
\text { term }\end{array}$ & $\begin{array}{l}\text { "Hard" techniques } \\
\text { used only during the } \\
\text { project }\end{array}$ & $\begin{array}{l}\text { Combination of 'hard' and } \\
\text { ecoengineering techniques } \\
\text { for short and long-term }\end{array}$ & $\begin{array}{c}\text { Combination of 'hard' } \\
\text { and eco-engineering } \\
\text { temp works becoming } \\
\text { permanent stuctures } \\
\end{array}$ & $\begin{array}{c}\text { Eco-engineering } \\
\text { temporary works } \\
\text { becoming permanent } \\
\text { works } \\
\end{array}$ & 1 \\
\hline Temporary works (drainage) & $\begin{array}{l}\text { "Hard' techniques } \\
\text { used only for short } \\
\text { term }\end{array}$ & $\begin{array}{l}\text { "Hard" techniques } \\
\text { used in short term } \\
\text { with possibility of } \\
\text { replacing with eco- } \\
\text { engineering } \\
\text { techniques in long- } \\
\text { term } \\
\end{array}$ & $\begin{array}{l}\text { Combination of 'hard' and } \\
\text { ecoengineering techniques } \\
\text { for short and long-term }\end{array}$ & $\begin{array}{l}\text { Combination of 'hard' } \\
\text { and eco-engineering } \\
\text { temp works becoming } \\
\text { permanent stuctures }\end{array}$ & $\begin{array}{c}\text { Eco-engineering } \\
\text { temporary works } \\
\text { becoming permanent } \\
\text { works }\end{array}$ & 1 \\
\hline Construction costs & \begin{tabular}{|c|} 
Transportation \\
projects: $>10 \%$ of \\
total project cost; \\
Energy projects: $>3 \%$; \\
Recreational \\
projects: $>9 \%$ \\
\end{tabular} & \begin{tabular}{|c|} 
Transportation \\
projects: $8-10 \%$ of total \\
project cost; Energy \\
projects: $1-3 \% ;$ \\
Recreational projects: \\
$7-9 \%$ \\
\end{tabular} & $\begin{array}{c}\text { Transportation projects: } 8 \% \\
\text { of total project cost; Energy } \\
\text { projects: } 1 \% \text {; Recreational } \\
\text { projects: } 7 \%\end{array}$ & $\begin{array}{c}\text { Transportation } \\
\text { projects: } 5-8 \% \text { of total } \\
\text { project cost; Energy } \\
\text { projects: } 0.5-1 \% ; \\
\text { Recreational projects: } 5 \text { - } \\
7 \% \\
\end{array}$ & $\begin{array}{l}\text { Transportation projects: } \\
<5 \% \text { of total project cost; } \\
\text { Energy projects: }<0.5 \% \\
\text { Recreational projects: } \\
<5 \%\end{array}$ & 2 \\
\hline Biodiversity & $\begin{array}{l}\text { Not considered } \\
\text { during construction }\end{array}$ & $\begin{array}{c}\text { Site biodiversity } \\
\text { appraisal carried out }\end{array}$ & $\begin{array}{c}\text { Site-level biodiversity } \\
\text { action plan created and } \\
\text { adhered to }\end{array}$ & Habitat(s) created & $\begin{array}{l}\text { Existing habitat(s) } \\
\text { protected and enhanced }\end{array}$ & 2 \\
\hline Total & & & & & & 2.8 \\
\hline
\end{tabular}


Table 6 Sustainability performance of the case study project during the Demobilisation stage.

\begin{tabular}{|c|c|c|c|c|c|c|}
\hline \multicolumn{2}{|c|}{ Stage F - Demobilisation } & \multicolumn{3}{|c|}{ Effect on Sustainability } & \multirow[b]{2}{*}{ Significantly improved } & \multirow[b]{2}{*}{ Score } \\
\hline Indicator & Harmful & Reduction & Neutral & Improved & & \\
\hline $\begin{array}{l}\text { How much plant is } \\
\text { reused? }\end{array}$ & Majority unusable & $\begin{array}{l}\text { Majority with } \\
\text { maintenance }\end{array}$ & $\begin{array}{c}\text { All reused but with } \\
\text { everything needing } \\
\text { maintenance }\end{array}$ & $\begin{array}{l}\text { All reused with some } \\
\text { needing maintenance }\end{array}$ & $\begin{array}{l}\text { All reused; maintenance } \\
\text { free }\end{array}$ & 3 \\
\hline $\begin{array}{l}\text { Where will } \\
\text { equipment go on } \\
\text { demobilisation? }\end{array}$ & $\begin{array}{l}\text { All equipment } \\
\text { returned to central } \\
\text { storage }\end{array}$ & $\begin{array}{c}\text { Majority of } \\
\text { equipment returned } \\
\text { to central storage }\end{array}$ & $\begin{array}{c}\text { 50:50 between next job } \\
\text { and storage }\end{array}$ & $\begin{array}{l}\text { Majority to another } \\
\text { site directly }\end{array}$ & $\begin{array}{l}\text { All equipment to another } \\
\text { site directly }\end{array}$ & 3 \\
\hline $\begin{array}{l}\text { Did the project } \\
\text { overrun on time? }\end{array}$ & $\begin{array}{l}\text { Completed very late } \\
\text { (>5\% of specified } \\
\text { project time) }\end{array}$ & Completed late & Completed on time & Completed early & $\begin{array}{c}\text { Completed very early ( }>5 \% \\
\text { of specified project time) }\end{array}$ & 2 \\
\hline $\begin{array}{l}\text { Did the project } \\
\text { overrun on cost? }\end{array}$ & $>10 \%$ cost overrun & $5-10 \%$ cost overrun & $\begin{array}{l}\text { On target (within } 5 \% \text { of } \\
\text { cost) }\end{array}$ & $5-10 \%$ cost saving & $>10 \%$ cost saving & 3 \\
\hline Total & & & & & & 2.8 \\
\hline
\end{tabular}


Table 7 Sustainability performance of the case study project during the Monitoring stage. Newly developed KPI shown in red.

\begin{tabular}{|c|c|c|c|c|c|c|}
\hline \multirow{2}{*}{$\frac{\text { Stage G - Monitoring }}{\text { Indicator }}$} & \multicolumn{4}{|c|}{ Effect on Sustainability } & \multirow[b]{2}{*}{ Significantly improved } & \multirow[b]{2}{*}{ Score } \\
\hline & Harmful & Reduction & Neutral & Improved & & \\
\hline $\begin{array}{l}\text { How are monitoring } \\
\text { stations powered? }\end{array}$ & $\begin{array}{l}\text { Manned } \\
\text { intervention } \\
\text { regularly required }\end{array}$ & $\begin{array}{c}\text { Manned } \\
\text { intervention } \\
\text { occasionally } \\
\text { required } \\
\end{array}$ & $\begin{array}{l}\text { Manned intervention } \\
\text { rarely required }\end{array}$ & $\begin{array}{l}\text { Remote data collection } \\
\text { from conventional } \\
\text { energy source (battery) }\end{array}$ & $\begin{array}{c}\text { Remote data collection } \\
\text { from sustainable energy } \\
\text { source (e.g. solar) }\end{array}$ & 5 \\
\hline Contingency planning & $\begin{array}{c}\text { Monitoring data not } \\
\text { used }\end{array}$ & $\begin{array}{c}\text { Data collected but } \\
\text { no plan in place }\end{array}$ & $\begin{array}{c}\begin{array}{c}\text { Plan in place but not } \\
\text { linked to data }\end{array} \\
\end{array}$ & $\begin{array}{c}\text { Plan covers treatment } \\
\text { linked to data }\end{array}$ & Plan covers all aspects & 5 \\
\hline $\begin{array}{l}\text { How long is monitoring } \\
\text { necessary? }\end{array}$ & $\begin{array}{l}>12 \text { months after } \\
\text { end of site works }\end{array}$ & $\begin{array}{l}\text { 6-12months after } \\
\text { end of site works }\end{array}$ & $\begin{array}{c}\text { 3-6months after end of } \\
\text { site works }\end{array}$ & $\begin{array}{c}0-3 \text { months after end of } \\
\text { site works }\end{array}$ & $\begin{array}{c}\text { Completed by end of site } \\
\text { works }\end{array}$ & 1 \\
\hline $\begin{array}{l}\text { Do monitoring systems } \\
\text { interfere with the } \\
\text { environment? }\end{array}$ & $\begin{array}{l}\text { Equipment causes } \\
\text { local stakeholder } \\
\text { complaints }\end{array}$ & $\begin{array}{l}\text { Equipment requires } \\
\text { frequent visits to } \\
\text { gather data }\end{array}$ & \begin{tabular}{|c|} 
Equipment placed \\
outside project \\
boundary with local \\
stakeholder \\
consultation \\
\end{tabular} & $\begin{array}{c}\text { Equipment placed } \\
\text { outside project } \\
\text { boundary but operates } \\
\text { remotely }\end{array}$ & $\begin{array}{l}\text { None outside project } \\
\text { boundary }\end{array}$ & 5 \\
\hline \multicolumn{7}{|c|}{ Technique specific stage G monitoring indicators } \\
\hline Erosion/wear monitoring & No monitoring & $\begin{array}{c}\text { Periodic/sporadic } \\
\text { site visits/surveys } \\
\text { without } \\
\text { quantitative data } \\
\text { collection } \\
\end{array}$ & $\begin{array}{l}\text { Periodic visits and/or } \\
\text { aerial surveys with } \\
\text { quantitative data } \\
\text { collection }\end{array}$ & $\begin{array}{c}\text { Periodic monitoring } \\
\text { (e.g. people counting } \\
\text { systems) and reporting } \\
\text { including quantitative } \\
\text { analysis } \\
\end{array}$ & $\begin{array}{l}\text { Continued monitoring of } \\
\text { erosion beyond the } \\
\text { statutory duty, connected } \\
\text { to analysis of } \\
\text { meteorological data }\end{array}$ & 1 \\
\hline Stability monitoring & No monitoring & $\begin{array}{l}\text { Periodic/sporadic } \\
\text { site visits/surveys } \\
\text { without } \\
\text { quantitative data } \\
\text { collection }\end{array}$ & $\begin{array}{l}\text { Periodic visits and/or } \\
\text { stability surveys with } \\
\text { quantitative data } \\
\text { collection }\end{array}$ & $\begin{array}{l}\text { Periodic monitoring } \\
\text { (e.g. laser 3D surveys; } \\
\text { UAV surveys) and } \\
\text { reporting including } \\
\text { quantitative analysis }\end{array}$ & $\begin{array}{l}\text { Continued monitoring of } \\
\text { stability (e.g. } \\
\text { inclinometers) beyond the } \\
\text { statutory duty, connected } \\
\text { to analysis of } \\
\text { meteorological and } \\
\text { vegetation data }\end{array}$ & 1 \\
\hline $\begin{array}{l}\text { Water / groundwater } \\
\text { monitoring }\end{array}$ & No monitoring & $\begin{array}{c}\text { Periodic/sporadic } \\
\text { site visits/surveys } \\
\text { without } \\
\text { quantitative data } \\
\text { collection }\end{array}$ & $\begin{array}{l}\text { Periodic visits with } \\
\text { quantitative data } \\
\text { collection (e.g. } \\
\text { groundwater levels) }\end{array}$ & $\begin{array}{l}\text { Periodic monitoring } \\
\text { (e.g. piezometers) and } \\
\text { reporting including } \\
\text { quantitative analysis }\end{array}$ & $\begin{array}{l}\text { Continued monitoring of } \\
\text { water/groundwater } \\
\text { flow/levels (e.g. real time } \\
\text { wireless sensing) beyond } \\
\text { the statutory duty, } \\
\text { connected to analysis of } \\
\text { meteorological and } \\
\text { stability data }\end{array}$ & 4 \\
\hline Biodiversity & No monitoring & $\begin{array}{c}\text { Periodic/sporadic } \\
\text { site visits/surveys } \\
\text { without } \\
\text { quantitative data } \\
\text { collection } \\
\end{array}$ & $\begin{array}{l}\text { Periodic visits with } \\
\text { quantitative data } \\
\text { collection }\end{array}$ & $\begin{array}{l}\text { Periodic monitoring } \\
\text { and reporting including } \\
\text { quantitative analysis }\end{array}$ & $\begin{array}{l}\text { Continued monitoring of } \\
\text { biodiversity beyond the } \\
\text { statutory duty, detailed in a } \\
\text { handover manual }\end{array}$ & 1 \\
\hline Total & & & & & & 2.9 \\
\hline
\end{tabular}


Table 8 Sustainability performance of the case study project for Long Term performance. Newly developed KPI shown in red.

\begin{tabular}{|c|c|c|c|c|c|c|}
\hline \multirow{2}{*}{$\begin{array}{c}\text { Stage } \mathrm{H} \text { - Long term } \\
\text { Indicator }\end{array}$} & \multicolumn{3}{|c|}{ Effect on Sustainability } & \multirow[b]{2}{*}{ Improved } & \multirow[b]{2}{*}{ Significantly improved } & \multirow[b]{2}{*}{ Score } \\
\hline & Harmful & Reduction & Neutral & & & \\
\hline $\begin{array}{c}\text { Land rendered usable } \\
\text { that was previously } \\
\text { unusable }\end{array}$ & $\begin{array}{l}\text { Land loss } \\
\text { increased }\end{array}$ & No change & $\begin{array}{l}\text { Partial reuse of } \\
\text { site }\end{array}$ & $\begin{array}{l}100 \% \text { but with no } \\
\text { recreational } \\
\text { facilities }\end{array}$ & $\begin{array}{l}100 \% \text { of the site with } \\
\text { some recreational } \\
\text { facilities }\end{array}$ & 5 \\
\hline $\begin{array}{l}\text { Land created for use by } \\
\text { business that } \\
\text { contributes to the local } \\
\text { economy }\end{array}$ & $\begin{array}{c}\text { No onflux of new } \\
\text { business }\end{array}$ & $\begin{array}{l}<20 \% \text { of site allocated to } \\
\text { new business }\end{array}$ & $\begin{array}{l}20 \%-50 \% \text { of site } \\
\text { allocated to new } \\
\text { business }\end{array}$ & $\begin{array}{l}\text { Majority of site } \\
\text { allocated to new } \\
\text { business }\end{array}$ & $\begin{array}{l}\text { Whole site allocated to } \\
\text { new business }\end{array}$ & 2 \\
\hline 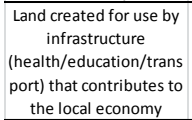 & $\begin{array}{l}\text { No onflux of new } \\
\text { infrastructure }\end{array}$ & $\begin{array}{l}<20 \% \text { of site allocated to } \\
\text { new infrastructure }\end{array}$ & $\begin{array}{l}20 \%-50 \% \text { of site } \\
\text { allocated to new } \\
\text { infrastructure }\end{array}$ & $\begin{array}{l}\text { Majority of site } \\
\text { allocated to new } \\
\text { infrastructure }\end{array}$ & $\begin{array}{l}\text { Whole site allocated to } \\
\text { new infrastructure }\end{array}$ & 2 \\
\hline Maintenance & $\begin{array}{c}\text { Regular } \\
\text { maintenance } \\
\text { required with } \\
\text { material/plant } \\
\text { input } \\
\end{array}$ & $\begin{array}{l}\text { Periodical maintenance } \\
\text { required with } \\
\text { material/plant input }\end{array}$ & $\begin{array}{c}\text { Periodical } \\
\text { maintenance } \\
\text { required without } \\
\text { material/plant } \\
\text { input } \\
\end{array}$ & \begin{tabular}{|c|} 
Occasional \\
maintenance \\
required without \\
material/plant \\
input
\end{tabular} & No maintenance required & 4 \\
\hline Client satisfaction & $<50 \%$ & $50 \%-70 \%$ & $70 \%-85 \%$ & $85 \%-98 \%$ & $98 \%-100 \%$ & 5 \\
\hline Client feedback & No debrief & Internal feedback only & $\begin{array}{l}\text { Feedback available } \\
\text { if asked for by } \\
\text { client }\end{array}$ & $\begin{array}{l}\text { Full debrief to } \\
\text { client at project } \\
\text { team level }\end{array}$ & $\begin{array}{l}\text { Full debrief to client at } \\
\text { director level }\end{array}$ & 5 \\
\hline Defect raised & $\begin{array}{l}>1 \text { defect not } \\
\text { correctable }\end{array}$ & $\begin{array}{l}\text { Single defect not } \\
\text { correctable }\end{array}$ & $\begin{array}{l}>1 \text { defect } \\
\text { corrected }\end{array}$ & $\begin{array}{c}\text { single defect } \\
\text { corrected }\end{array}$ & No defects & 3 \\
\hline Benchmarking & $\begin{array}{c}\text { Company } \\
\text { unaware of KPIs }\end{array}$ & $\begin{array}{c}\begin{array}{c}\text { No benchmarking on the } \\
\text { project but company has a } \\
\text { KPI policy in place }\end{array} \\
\end{array}$ & $\begin{array}{c}\text { Minimum number } \\
\text { of aspects } \\
\text { benchmarked }\end{array}$ & $\begin{array}{c}\text { Partial aspects of } \\
\text { the project } \\
\text { benchmarked }\end{array}$ & $\begin{array}{c}\text { All aspects of the project } \\
\text { benchmarked }\end{array}$ & 1 \\
\hline $\begin{array}{c}\text { Did the project overrun } \\
\text { on time? }\end{array}$ & $\begin{array}{c}\begin{array}{c}\text { Completed very } \\
\text { late }(>5 \% \text { of } \\
\text { specified project } \\
\text { time) }\end{array} \\
\end{array}$ & Completed late & $\begin{array}{l}\text { Completed on } \\
\text { time }\end{array}$ & Completed early & $\begin{array}{c}\text { Completed very early } \\
\text { (>5\% of specified project } \\
\text { time) }\end{array}$ & 2 \\
\hline $\begin{array}{l}\text { Did the project overrun } \\
\text { on cost? }\end{array}$ & $\begin{array}{c}>10 \% \text { cost } \\
\text { overrun }\end{array}$ & 5-10\% cost overrun & $\begin{array}{l}\text { On target (within } \\
5 \% \text { of cost) }\end{array}$ & 5-10\% cost saving & $>10 \%$ cost saving & 3 \\
\hline $\begin{array}{c}\text { Information plan with } \\
\text { local community }\end{array}$ & $\begin{array}{c}\text { Actively avoiding } \\
\text { interaction }\end{array}$ & None & Basic & $\begin{array}{l}\text { Detailed using } \\
\text { single medium }\end{array}$ & $\begin{array}{c}\text { Planned programme of } \\
\text { community PR }\end{array}$ & 5 \\
\hline $\begin{array}{l}\text { Insurance and } \\
\text { warranties }\end{array}$ & $\begin{array}{c}\text { Remediation } \\
\text { choice unable to } \\
\text { be insured }\end{array}$ & $\begin{array}{c}\text { Remediation choice } \\
\text { increases insurance costs }\end{array}$ & $\begin{array}{c}\text { Standard insurance } \\
\text { costs }\end{array}$ & $\begin{array}{c}\text { Remediation } \\
\text { reduces insurance } \\
\text { costs }\end{array}$ & $\begin{array}{l}\text { Remediation significantly } \\
\text { reduces insurance costs }\end{array}$ & 3 \\
\hline \multicolumn{7}{|c|}{ Technique specific stage $\mathrm{H}$ Long term indicators } \\
\hline $\begin{array}{c}\text { Effective ground cover } \\
\text { (seeding and matting) at } \\
\text { commissioning }\end{array}$ & $<30 \%$ & $30-45 \%$ & $45-55 \%$ & $55-75 \%$ & $75-100 \%$ & 2 \\
\hline \begin{tabular}{c|c|} 
Planted shrub/tree \\
survival rate at \\
commissioning \\
\end{tabular} & $<50 \%$ & $50-70 \%$ & $70 \%$ & $70-90 \%$ & $90-100 \%$ & 4 \\
\hline $\begin{array}{l}\text { Replacement of dead } \\
\text { and failed plants }\end{array}$ & None & Re-seeding & $\begin{array}{c}\text { Replacement of } \\
\text { non-thriving plants }\end{array}$ & Re-planting gaps & $\begin{array}{c}\text { Removal of out of } \\
\text { specification shrubs/trees }\end{array}$ & 3 \\
\hline Irrigation & $\begin{array}{l}\text { Full irrigation } \\
\text { system for long } \\
\text { term }\end{array}$ & $\begin{array}{l}\text { Irrigation system using } \\
\text { mains supply and/or } \\
\text { conventional energy } \\
\text { sources }\end{array}$ & $\begin{array}{l}\text { Full irrigation } \\
\text { system in short } \\
\text { term using } \\
\text { recycled water and } \\
\text { renewable energy }\end{array}$ & $\begin{array}{l}\text { Occasional, } \\
\text { scheduled }\end{array}$ & $\begin{array}{l}\text { Occasional (none), based } \\
\text { on regular inspection }\end{array}$ & 2 \\
\hline Mowing & $\begin{array}{c}>3 \text { cuts in the first } \\
3 \text { years }\end{array}$ & $1-3$ cuts in the first 3 years & Single cut specified & $\begin{array}{c}\text { Single cut based } \\
\text { on regular } \\
\text { inspection }\end{array}$ & None & 5 \\
\hline Mulching & $\begin{array}{l}\text { Non- } \\
\text { biodegradable } \\
\text { mulch }\end{array}$ & None & $\begin{array}{c}\text { Combination of } \\
\text { bio- and non- } \\
\text { biodegradable } \\
\text { mulch } \\
\end{array}$ & $\begin{array}{l}\text { Biodegradable } \\
\text { mulch }\end{array}$ & $\begin{array}{l}\text { Locally sourced } \\
\text { biodegradable mulch }\end{array}$ & 2 \\
\hline Pruning & $\begin{array}{l}\text { Specified during } \\
\text { first } 10 \text { years }\end{array}$ & $\begin{array}{l}\text { Specified during first } 5 \\
\text { years }\end{array}$ & None & $\begin{array}{c}\text { During first two } \\
\text { years after } \\
\text { commissioning }\end{array}$ & $\begin{array}{c}\text { As/if needed during first } \\
\text { two years, based on } \\
\text { inspection }\end{array}$ & 3 \\
\hline Staking and tying & None & No category & $\begin{array}{l}1 \text { year with repair } \\
\text { and replacement }\end{array}$ & No category & $\begin{array}{l}\text { 3-5 years with } \\
\text { repair/replacement, } \\
\text { based on regular } \\
\text { inspection }\end{array}$ & 3 \\
\hline Fertilising & None & No category & $\begin{array}{c}\text { Fertilisation } \\
\text { programme/specif } \\
\begin{array}{c}\text { ication for short } \\
\text { term only }\end{array} \\
\end{array}$ & No category & $\begin{array}{l}\text { Fertilisation programme } \\
\text { for short and long term }\end{array}$ & 1 \\
\hline Woodland management & None & General prunning & $\begin{array}{c}\text { Pruning of } \\
\text { deceased parts }\end{array}$ & $\begin{array}{l}\text { Thinning, heavy } \\
\text { prunning }\end{array}$ & $\begin{array}{l}\text { Pruning to obtain fresh } \\
\text { planting material } \\
\text { (coppicing, pollarding) }\end{array}$ & 1 \\
\hline $\begin{array}{c}\begin{array}{c}\text { Erosion/wear (e.g. from } \\
\text { recreation) }\end{array} \\
\end{array}$ & $\begin{array}{c}\begin{array}{c}\text { None / not } \\
\text { measured }\end{array} \\
\end{array}$ & High & Moderate & Medium & Low & 1 \\
\hline Reinstatement works & Route alteration & No category & Temp. fencing & No category & No closures & 3 \\
\hline Emergency works & Route alteration & No category & Temp. fencing & No category & No closures & \\
\hline $\begin{array}{l}\text { Provision of future } \\
\text { services }\end{array}$ & $\begin{array}{c}\text { Treated area } \\
\text { unable to be } \\
\text { excavated for } \\
\text { installation of } \\
\text { services } \\
\end{array}$ & $\begin{array}{l}\text { Treated area creates } \\
\text { complications for } \\
\text { installation of services }\end{array}$ & $\begin{array}{c}\text { Treated area } \\
\text { presents no } \\
\text { problems for } \\
\text { future excavations }\end{array}$ & $\begin{array}{l}\text { Clean gravel } \\
\text { trenches built in to } \\
\text { allow future } \\
\text { services }\end{array}$ & $\begin{array}{l}\text { Treated area linked to } \\
\text { design to minimise } \\
\text { disruption of future } \\
\text { services }\end{array}$ & 1 \\
\hline Stability & $\begin{array}{l}\text { Shallow and deep- } \\
\text { seated instability } \\
\text { incl. erosion, } \\
\text { vegetation } \\
\text { displaced }\end{array}$ & No category & $\begin{array}{l}\text { Minor shallow } \\
\text { instability, minor } \\
\text { erosion, } \\
\text { vegetation not } \\
\text { displaced or } \\
\text { overturned }\end{array}$ & No category & No instability & 5 \\
\hline Durability & $\begin{array}{l}\text { Monitoring } \\
\text { increased for a } \\
\text { long period }\end{array}$ & $\begin{array}{l}\text { Monitoring increased for a } \\
\text { short period (months) }\end{array}$ & $\begin{array}{l}\text { Monitoring } \\
\text { matching plan } \\
\text { estimate }\end{array}$ & $\begin{array}{l}\text { Monitoring } \\
\text { reduced to } \\
\text { minimum }\end{array}$ & $\begin{array}{c}\text { Natural progression and } \\
\text { succession takes place; } \\
\text { monitoring becomes } \\
\text { obsolete }\end{array}$ & 4 \\
\hline Total & & & & & & 3.0 \\
\hline
\end{tabular}

